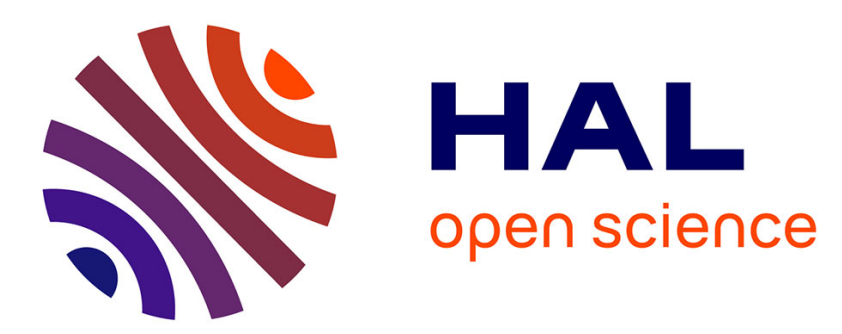

\title{
Anatomy of an extensional shear zone leading to the exhumation of the middle crust within the Canigou dome (Eastern Pyrenees, Axial Zone) B. Le Bayon, Bryan Cochelin
}

\section{- To cite this version:}

B. Le Bayon, Bryan Cochelin. Anatomy of an extensional shear zone leading to the exhumation of the middle crust within the Canigou dome (Eastern Pyrenees, Axial Zone). Journal of Structural Geology, 2020, 141, pp.104200. 10.1016/j.jsg.2020.104200 . insu-02964669

HAL Id: insu-02964669

https://hal-insu.archives-ouvertes.fr/insu-02964669

Submitted on 12 Oct 2020

HAL is a multi-disciplinary open access archive for the deposit and dissemination of scientific research documents, whether they are published or not. The documents may come from teaching and research institutions in France or abroad, or from public or private research centers.
L'archive ouverte pluridisciplinaire HAL, est destinée au dépôt et à la diffusion de documents scientifiques de niveau recherche, publiés ou non, émanant des établissements d'enseignement et de recherche français ou étrangers, des laboratoires publics ou privés. 


\section{Journal Pre-proof}

Anatomy of an extensional shear zone leading to the exhumation of the middle crust within the Canigou dome (Eastern Pyrenees, Axial Zone)

B. Le Bayon, B. Cochelin

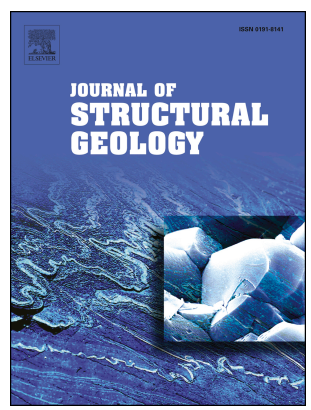

PII:

S0191-8141(20)30420-X

DOI: $\quad$ https://doi.org/10.1016/j.jsg.2020.104200

Reference: $\quad$ SG 104200

To appear in: Journal of Structural Geology

Received Date: 24 September 2020

Accepted Date: 25 September 2020

Please cite this article as: Bayon, B.L., Cochelin, B., Anatomy of an extensional shear zone leading to the exhumation of the middle crust within the Canigou dome (Eastern Pyrenees, Axial Zone), Journal of Structural Geology, https://doi.org/10.1016/j.jsg.2020.104200.

This is a PDF file of an article that has undergone enhancements after acceptance, such as the addition of a cover page and metadata, and formatting for readability, but it is not yet the definitive version of record. This version will undergo additional copyediting, typesetting and review before it is published in its final form, but we are providing this version to give early visibility of the article. Please note that, during the production process, errors may be discovered which could affect the content, and all legal disclaimers that apply to the journal pertain.

(C) 2020 Elsevier Ltd. All rights reserved. 
2 Anatomy of an extensional shear zone leading to the exhumation of the middle

3 crust within the Canigou dome (Eastern Pyrenees, Axial Zone)

B. LE BAYON ${ }^{\mathrm{a} *}$, B. COCHELIN ${ }^{\mathrm{b}}$

a) BRGM, 3 avenue claude Guillemin, BP 36009, 45060 Orléans cedex 2

b) Université Orléans, CNRS, BRGM, ISTO, UMR 7327, 1 A Rue de la Ferollerie, 45071 Orléans, France

* corresponding author: b.lebayon@brgm.fr, tel: (Fr) 00332386446 51; 3 avenue Claude Guillemin BP36009, 45060 Orléans cédex 2 France.

9

Keywords: Canigou, gneiss dome, strain localization, transpression, Puigmal, synconvergence extension 


\section{Abstract}

To investigate the mechanism of exhumation of deep crustal rocks in hot orogens, we focus on the southwestern part of the Variscan Canigou gneiss dome (Pyrenees) where the transition between the middle and upper crust can be observed. On the basis of new structural data, geological mapping, cross sections, microstructural analyses, and petrologic observations, we propose that flat-lying foliation within the gneiss dome and steep cleavage developed above it formed coevally. We note the presence of regionalscale shear zones at the boundary between the middle crust (Núria-Canigou Unit) and upper crust (Puigmal unit). At this boundary, the E-W South Canigou Shear Zone is an extensional shear zone showing top-to-the- southwest kinematics. Deformation, which is localized within the andalusite-biotite transition zone, occurred under retrogressive conditions, from high-grade ductile to brittle conditions during the main deformation stage (D2). The tectonic contact was folded during a later stage (D3). We propose that the shape of the Canigou dome resulted from the activation of extensional shear zones at the top of the orthogneiss, leading to partial exhumation of high-grade rocks. The Canigou gneiss dome can be considered an extensional dome that formed during late Variscan (ca. 310-290Ma) transpression. 


\section{Introduction}

Gneiss domes are structural domes that have primarily high-grade gneissic rocks (migmatite, orthogneiss) and granites at their cores; they are mantled by schists and gneiss, mostly showing lower grade metamorphic facies. These gneiss domes are common features in mountain belts, but their origin is still debated. It is known that, various mechanisms associated with different geodynamical contexts produce dome-shaped structures. By studying them, we increase our understanding of the exhumation of crustal metamorphic rocks (Whitney et al., 2004 and references therein). The primary models can be summarized as follows: (i) postmetamorphic folding (Matte et al., 1998); (ii) synorogenic extension (e.g., Lister et al., 1984; Lister and Davis, 1989; Burg et al., 1994, and references therein), wrenching (e.g., in releasing bends, Denèle et al., 2017), or transpression (e.g., Rabin et al., 2015). In the first case, exhumation during folding is passive and is caused by erosion whereas active exhumation results from strain localization at gneiss domes gneiss dome envelopes in the other cases (wrenching \& transpression). Exhumation also implies contrasting crustal rheology: i) a relatively cold crust for post-metamorphic folding (e.g., Brun, 2002) and ii) a weak and partially molten crust for the other models (Tirel et al., 2008).

The Variscan orogeny of western Europe is characterized by the formation of numerous gneiss domes from the collision stage at ca. $360 \mathrm{Ma}$ until the end of its collapse at ca. $300 \mathrm{Ma}$ (e.g., Faure et al., 2009; Gapais et al., 2015 and references therein). In the hinterland of the belt, the High Temperature/Medium Pressure (HT/MP) rocks were mostly exhumed under late-orogenic extensional conditions, leading to the formation of Metamorphic Core Complexes (Armorican massif, French Massif Central), (Van Den Driessche and Brun, 1992; Ledru et al. 2001; Gapais et al. 2015), locally with strike-slip component (e.g. Montagne noire, Franke et al., 2011; Roger et al., 2015). Although the late Variscan HT/LP metamorphic event reached the belt foreland 
at $315 \mathrm{Ma}$, the mode of gneiss dome formation there continues to be debated, as in the Pyrenees (Denèle et al. 2014).

In fact, the ascent of deep rocks leading to the formation of metamorphic domes (Figure 1) in the Pyrenees has been explained by various mechanisms associated with different geodynamical contexts. The first models proposed for the exhumation of these rocks involve two primary mechanisms: (i) a post-metamorphic folding (Guitard, 1964; 1967; 1970) which involves a post-metamorphic folding phase, or (ii) diapirism (Pouget,1987, 1991; Soula, 1982; Soula et al., 1986) essentially related to extrusion by thrusting (Aguilar et al. 2015). Considering that the mid-lower crust was partially molten, recent studies suggest that domal structures were formed by folding after an initial stage of horizontal flow within the mid-lower crust under dextral transpression (Vilà et al., 2007; Denèle et al., 2007, 2009; Mezger, 2009). Alternatively, several models propose exhumation with local extension as a result of strain localization in regional shear zones (Bossòst dome: Mezger and Passchier, 2003; Cochelin et al., 2017; Hospitalet massif: Van den Eeckhout and Zwart, 1988; Basque and North Pyrenean massifs: de Saint Blanquat, 1993; Saspiturry et al., 2019; Vanardois et al., 2020).

Whereas some relicts of Barrovian metamorphism suggest that moderate crustal thickening occurred in the Pyrenees during the late Carboniferous convergence phase (Azambre and Guitard, 2001; De Hoÿm de Marien et al., 2019), the existence of early Variscan nappes in the Axial Zone was mostly inferred but the nature of these contacts remains highly disputed (e.g., Bodin and Ledru, 1986; Losantos et al, 1986; Cochelin et al., 2017). In fact, new structural studies highlight that i) the early convergence phase, called D1, was primarily characterized by thin-skinned rather than thick-skinned tectonics and nappe formation a during Variscan time (Cochelin et al., 2017), and ii) the main Variscan thrusts that were recognized show only minor offset (i.e., no more than 1-2 km, see Cochelin et al., 2018a). 
To clarify the exhumation mode of crustal rocks that crop out within the Canigou gneiss dome, we present in this work a structural and petrological study conducted in the southwestern part of the Canigou gneiss dome, which was previously described as an early folded nappe (Guitard, 1970, Lagarde, 1978; Soliva et al., 1989, Laumonier and Autran, 2001). We provide a detailed structural analysis of the orthogneiss and surrounding metasediments that leads us to propose that the domal structure was formed by extension and strain localization at the top of a weak mid-lower crust under regional transpression. This study is based on new geological maps of the area drawn at a 1:50 000 scale (Prats de Mollo, Arles/Tech, and Mont-Louis).

Figure 1 here

\section{Geological setting}

\subsection{Variscan Pyrenees}

The Pyrenean orogeny resulted from the collision of the Iberian and Eurasian plates, which occurred from the late Cretaceous to the Miocene (e.g., Choukroune, 1992; Muñoz, 1992). This orogeny exhumed the Proterozoic to Paleozoic basement and its Mesozoic sediments. The main Paleozoic basement outcrops are located in the Axial Zone, between the North Pyrenean fault and the South Pyrenean thrust. Other Paleozoic basement outcrops are found in the North Pyrenean massifs and Basque massifs (Figure 1).

In the Pyrenees, the Variscan crust is composed of Ediacarian to Carboniferous metasediments. Lower Paleozoic metasediments were intruded by Ordovician plutons (Deloule et al., 2002 ; Cocherie et al., 2005 ; Casas et al., 2010; Liesa et al., 2011) and the entire sedimentary pile was affected by a late Variscan HT-LP event responsible for the emplacement of gneissic domes and Permo-Carboniferous granitoid intrusions (see Denèle et al. 2014 and references therein, Figure 1). From a structural point of view, the Variscan crust of the Axial Zone shows a strong structural contrast between (i) an upper crustal level, the so-called 
suprastructure (Zwart, 1979; Carreras and Capella, 1994), characterized by low-grade metasediments with upright folds associated with vertical schistosity and stretching direction (Cochelin et al. 2017; 2018a,b) and (ii) a lower crustal level, called the infrastructure, which consists of medium to high grade HT/LP foliated metamorphic rocks that form regional domal structures (Guitard et al., 1996, and references therein). These gneiss domes are affected by pervasive longitudinal stretching and subhorizontal shearing (Cochelin et al., 2017, 2018b).

Recent U-Pb dating on various magmatic bodies in the Eastern Pyrenees suggest that these domes formed between 310 and $290 \mathrm{Ma}$, synchronously to the emplacement of large calcalkaline plutons in the upper crust (Aguilar et al. 2014; Denèle et al. 2014 and references therein, Druguet et al., 2014; Esteban et al., 2015; Kilzi et al 2016; Lemirre et al., 2019; Poitrenaud et al., 2019, Vanardois et al., 2020). Locally, magmatism may have started earlier, at 330-340 Ma, as in the Central Pyrenees (Mezger \& Gerdès, 2016, Schnaperelle et al., 2020) but the significance of this earlier magmatism remains elusive (see the discussion in Denèle et al., 2014; Lopez-Sanchez et al., 2018). Structural studies performed within the calk-alkaline plutons show that they were synkinematic, and emplaced during a dextral transpressional phase, called D2 (e.g., Bouchez and Gleizes, 1995; Gleizes et al. 1998). On the basis of these new geochronological constraints and recent structural and petrological studies performed at the Hospitalet, Aston, Bossòst and Albères gneiss domes, recent opinion has favored a gneiss dome emplacement mode resulting from dextral transpression due to N-S horizontal shortening. It this emplacement mode has become the consensus since the 2000's (Mezger and Passchier, 2003; Vilà et al. 2007; Denèle et al, 2007, 2008, 2009; Mezger, 2009, Cochelin et al. 2017, Vanardois et al., 2020, among others). The N-S shortening that caused D2 transpression ultimately ended at ca. $290 \mathrm{Ma}$ with the development of anastomosed transpressional shear zones that formed under greenschist facies metamorphic conditions (e.g., Druguet, 2001; Cochelin et al., 2017; Poitrenaud et al., 2019). 
The D2 phase followed an earlier D1 phase in the Pyrenees that is related to the propagation of the Variscan front into the foreland of the belt between 325 and $310 \mathrm{Ma}$ (Delvolvé et al., 1993; Laumonier et al., 2014). Not many D1 structures survived the impact of the primary D2 phase. Most of D1 structures can be observed in the upper crust and are characterized by N-S to NW-SE trending recumbent or overturned folds associated with westward/southwestward thrusting (Cochelin et al., 2017). In some places, relicts of MT/MP metamorphism are present, suggesting moderate thickening of the crust during the D1 early convergence phase (e.g., Azambre and Guitard 2001; Mezger and Passchier, 2003; De Hoÿm de Marien et al., 2019).

This late Variscan event is followed by Permian extension/transtension that led to the formation of half-grabens that were filled by continental sediments and volcanics (e.g., Perreira et al., 2014; Gretter et al., 2015). Magmatism continued during Permian extension, highlighted by pluton emplacement (Denèle et al., 2011), intrusion of leucogranite dykes in the Axial Zone (Lemirre, 2018; Schnapperelle et al., 2020), and exhumation of migmatites and granulites from the Basque and North Pyrenean massifs by activation of extensional shear zones/detachment faults at the tops of metamorphic core complexes (de Saint Blanquat et al., 1990; de Saint Blanquat, 1993; Saspiturry et al., 2019).

\subsection{The Canigou gneiss dome}

The Canigou gneiss dome is located in the Axial Zone of the Pyrenees (Figure 1) between the Neogene Têt fault to the northwest and the Alpine Canigou thrust to the south (Figure 2). Canigou gneisses (named G1; G2; G3 by Guitard, 1953; 1970) underlie the Canigou massif and exhibit various petrological and geochemical characteristics. The Freser and Núria gneisses are located in the small gneissic complex that crops out in the Núria valley (Figure 2). 
The Canigou dome consists of abundant augen-gneisses derived from porphyritic granitoids that contain varying amounts of biotite, dated at $475+/-10 \mathrm{Ma}(\mathrm{U}-\mathrm{Pb}$ on zircons) in the Canigou gneissic complex (Deloule et al., 2002 ; Cocherie et al., 2005 ; Casas et al., 2010; Liesa et al., 2011) and ca. 457Ma in leucogranitic gneisses (Navidad et al., 2018) and the Núria and Freser gneissic complex (Martinez et al., 2010). Barbey et al. (2001) interpreted these granitic bodies as laccoliths. The laccoliths are embedded in Proterozoic to lower Cambrian metapelites (Cocherie et al., 2005 ; Castiñeiras et al., 2008) attributed to the Canaveilles formation (Guitard, 1970; Laumonier et al., 2004), which are called Balatg micashists beneath the primary laccolith in the Canigou dome (Figure 2). A recent study on the Balatg micaschists by de Hoÿm de Marien et al. (2019) reveals the presence of two syntectonic metamorphic stages: (i) a first tectono-metamorphic stage (D1-M1) associated with relict S1 foliation, preserved in the core of the Canigou dome, and (ii) a second tectono-metamorphic stage M2 (associated with the main S2 regional foliation) that records similar peak temperatures of $580^{\circ} \mathrm{C}$ at different pressure conditions of 5.5 for M1 and 3 kbar for M2. The whole sequence was subsequently intruded by two types of granites: i) peraluminous, such as the Canigou leucogranite ("granite profond du Canigou" (Guitard, 1970) and ii) calc-alkaline granitoids represented by the Costabonne Granite in this area (Figure 2). These calc-alkaline granites were emplaced during the late Carboniferous, according to LA-ICP-MS U/Pb in-situ dating on zircons: ca. $302 \mathrm{Ma}$ for the Costabonne granite (Laumonier et al., 2015) and ca. 303-305 Ma for Mont Louis (Romer and Soler, 1995; Maurel et al., 2004; Perreira et al., 2014; Denèle et al., 2014). A similar age of ca. $305 \mathrm{Ma}$ was obtained for peraluminous granites located at the northern part of the gneiss dome (Carança area, Denèle et al., 2014). The S2 foliation within the Canigou gneiss dome defines a regional E-W fold (Figure 2b) and foliation planes exhibit L2 mineral-stretching lineations that have a NE-SW trend (Guitard, 1964; Cochelin et al., 2018b, Figure 2a \& b). Within the Canigou dome country rock (i.e., the suprastructure), metasediments are affected by a pervasive N98E axial plane cleavage dipping moderately to the north and displaying NNW-SSE stretching 
lineations (Figure 2b, see Cochelin et al., 2017; 2018a). These L2 lineations are associated with south-southeastward thrusting or dextral kinematics, which is typical of deformation related to D2 dextral transpression in the Axial Zone (e.g., Denèle et al., 2008; Cochelin et al., 2018a; Poitrenaud et al., 2019).

Figure 3 here

Several models have been proposed to explain the emplacement of the Canigou gneissic complex (Figure 3). Barbey et al. (2001) described the Canigou dome as a laccolith, intruded during the Ordovician and later affected by weak Variscan deformation (Figure 3c). This model does not take into account the activity of shear zones in the Canigou gneiss dome during the Variscan orogeny, as proposed by Laumonier and Autran (2001) (e.g. the Puigmal contact, location in Figure 2). Unlike the crustal extension model (Gibson, 1991, Gibson and Bickle, 1994), which considers the predominant regional foliation to be related to retrograde metamorphism, other models invoke nappe stacking to explain the emplacement of the Canigou dome, described as a large recumbent fold (Autran \& Guitard, 1969; Guitard, 1970) (Figure 3a) or related to the thrust development with a top-to-the-SW sense of shear at the base and roof of the orthogneiss (Figure 3b) (Geyssant et al., 1978; Lagarde and Millot, 1978; Soliva, 1992). Laumonier and Autran (2001) proposed that the Canigou's dome shape resulted from late Variscan folding (i.e. after regional metamorphism) during N-S convergence.

To clarify the tectonic environment that led to the formation of the Canigou dome, we present new results based on (i) recent structural mapping and a reinterpretation of published maps of the southern part of the Canigou massif (Figure 4), (ii) systematic measurements of foliation and stretching lineations (Figure 5), (iii) recognition of shear criteria (Figure 5), and (iv) identification of strain gradients. 
Figure 4 here

Figure 5 here

\section{Structural data}

Based on a new cartographic study and the recognition of the Puigmal contact first described by Laumonier and Autran (2001), we define two main units in terms of their structural and metamorphic characteristics (Figure 4): (i) A lower unit, called the Núria -Canigou Unit and (ii) an upper unit, called the Puigmal Unit.

From bottom to top, we note:

(i) The Núria-Canigou unit, which consists of the Núria orthogneiss (Santanach, 1972, Robert, 1980, Sebastián et al., 1982) overlain by biotite-bearing micaschists and marble attributed to the Canaveilles formation (Laumonier et al., 2015),

(ii) The Puigmal tectonic contact, described as a major Variscan thrust by Laumonier and Autran (2001). Our structural study reveals new structural data on the geometry and kinematics of this major contact. We introduce the term South Canigou Shear Zone (SCSZ), to describe the high strain zone. The Puigmal tectonic contact is located in the uppermost part of the SCSZ. In fact, the SCSZ is well developed at the contact between the Canigou orthogneiss and micaschist, whereas the Puigmal contact, located near the Núria dome and at/to the south of the Canigou dome, is always present at the top of the SCSZ.

(iii) The Puigmal unit, which consists of weakly metamorphosed (at most in the chlorite zone) metasiltstones, metapelites and schists, identified as the Cabrils to Jujols formations; it has wellpreserved stratigraphy (Padel et al., 2017; 2018). 
The Canigou gneiss dome defines an elliptical map shape, and has a WSW-ENE axial

trend (Figure 2). It is characterized by a pervasive shallowly dipping schistosity (S2) that parallels the contact between the Canigou orthogneiss and metasediments (Figures 5, 6a \& b). This primary foliation is marked by quartz, feldspars (plagioclase grains and Kfs porphyroclasts) aggregates and biotite in the orthogneiss. In the Canigou gneiss dome micaschists, we observe a decreasing temperature gradient from the core of the dome shown by the following: sillimanite-bearing micaschists (Figure 7a), then andalusite-staurolite bearing micaschists (Figure 7b) followed by biotite micaschists (Figure 7c, d, e, f). These parageneses correspond to the M2 metamorphic assemblage in the lower unit of the study area. Large garnets contain numerous micrometric inclusions and larger inclusions of muscovite, quartz, and plagioclase that define a sigmoidal internal foliation (S1) (Figure 7c). S2 foliation displays mineral-stretching lineation (L2) (Figure 6b) that consists of alignment and stretching of biotite, plagioclase, and muscovite grains. In detail, L2 measurements] show a spread from E-W to N-S, despite a main trend approximately NE-SW (mean lineation: $225 \% 17^{\circ}$ ) (Fig. $5 \mathrm{~b}$ ). L2 is approximately E-W at the base of the orthogneiss on the eastern side of the dome (Figure 2) and in the Núria area, and shifts to N-S at the southern boundary of the Canigou gneiss dome near the contact with Canaveilles micaschists (roof of the laccolith) (Figures $2 \& 5$ ). In fact, though these stretching lineations are regularly oriented in the dome core, we observed a radial lineation distribution towards the Canigou dome margins (Figure 2). This main S2 foliation is affected by discrete shear bands that show stretching lineation parallel to mineral lineation lying on S2 planes. These shear bands exhibit a mainly downdip sense of shear in the core of the dome, with topto-the-WSW kinematics in the western part of Canigou and the Núria massif, and top-to-theENE kinematics at the eastern part of the Canigou gneiss dome (Figure. 2). Similarly, the sense of shear follows the radial distribution of L2, with top-to-the-NNW on the north flank of the gneiss dome and top-to-the-SSW on its southern flank (Figures 2, 5 \& 6a,b,e). 
In several thin sections we observed the development of oriented chlorite, formed at the expense of biotite, parallel to the main foliation S2. Chlorite occurrences appear to be located in a meter-scale mylonitic zone parallel to the $\mathrm{S} 2$ regional foliation (Figure $7 \mathrm{~d}, \mathrm{e}, \mathrm{f}$ ), suggesting that deformation occurred under retrogressive conditions (herein named $\mathrm{D} 2 \mathrm{~b}$ and $\mathrm{M} 2 \mathrm{~b}$ ) with progressive retrogression of biotite to chlorite.

\section{Figure 7 here}

\subsubsection{The South Canigou Shear Zone}

At the southern boundary of the Canigou dome, we observed a progressive transition upwards from augen-gneisses to fine-grained, augen-free mylonites (Figure 6c, d). The upper boundary thus corresponds to a hundreds of meters thick mylonitic zone at the contact with the metasediments (Figure 8), called here "the South Canigou Shear Zone" (SCSZ). Stretching lineations observed on the mylonitic foliation are parallel to the $\mathrm{L} 2$ observed below the contact, within foliated augen-gneiss, that plunges to the south/southwest along the southern limb of the Canigou gneiss dome. C' shear bands and sigma-clasts in the SCSZ indicate a top-to-the-SW sense of shear, which is compatible with the sense of shear observed at greater depth in the lower unit (Figure 6d). Above the contact between orthogneiss and micaschist, we observed several thin (around 10 meters thick) boudinaged marble layers within biotite, which are present at various levels of the SCSZ. This marble has isoclinal folding (Figure 6e), which may explain why carbonate layers are present throughout the metasedimentary sequence as sheared fold hinges and stretched fold limbs (Figure 8). In these metasediments, we observed a thin sheet of mylonitic leucocratic gneiss, called the "Bassibès sill," which is mapped from Cambre d'Aze to Pic de l'Enfer (Autran, 1986; Laumonier et al., 2015) (Figure 4). Similar sheets of mylonitic orthogneiss have been mapped in the same structural position, in the metasedimentary 
sequence above Setcases ("Baga de Carboner sill") and above La Preste (Location Fig. 2; Laumonier et al., 2015). In the La Preste area (east of our study area), the southern boundary of Canigou orthogneiss appears to be less deformed. There, the SCSZ described above should be located in the micaschist and marble or may have been shifted or obliterated by later normal faulting and by Alpine thrusting (i.e., the "chevauchement frontal du Canigou", Guitard, 1970), which has reworked the southeastern boundary of the Canigou gneiss dome (Figure 2).

Figure 8 here

\subsection{The Puigmal tectonic contact}

This contact is well exposed on the western side of Núria Valley (Figure 4). At the top of the lower unit, a zone of dark schists (phyllonites), approximately $30 \mathrm{~m}$ thick exhibits pervasive schistosity. This is the Puigmal contact which can also be observed in the valley of Coma de l'Embut (Figure 9) and above Fontalba (Figure 10). In many places, carbonates (dolomites) are associated with this black schist and are tectonically brecciated as observed above Fontalba (Figures 9a \& 10a,b). A few meters above the contact, this schistosity becomes a discrete crenulation cleavage, an axial plane of folds that deformed an earlier planar fabric defined by a quartz-muscovite-plagioclase assemblage (S0-1) (Figure 7f). At the Puigmal contact, the $\mathrm{S0}-1$ is completely obliterated, with only rare relics preserved (Figures 7e, 9). A strain gradient can be observed, especially in the upper unit. Strain increases downwards, as indicated by the progressive development of increasingly more pervasive schistosity (Figure 9c) (dipping $30^{\circ}$ to the north), which is the N100 axial plane of folds (Figure 9a,b). At the contact, these folds are isoclinal and S2 schistosity is pervasive (Figure 7e).

In this highly deformed zone, stretching lineations are primarily highlighted by quartz aggregates or recrystallized limestones, that are oriented parallel to those in lower units. From a kinematic point of view, drag folds, C' shear bands with top-to-south or southwest sense of shear, are present. 
Figure 9 here

\subsection{The Puigmal Unit (Upper unit)}

304

In the study area, metasedimentary rocks are affected by open to tight E-W trending folds that show well-preserved stratigraphy, except in the vicinity of the Puigmal contact. These folds are associated with a discrete N96E axial plane cleava ge (Figure $5 b$ ), which we will hereafter call primary S2 "schistosity". In detail, approaching the Puigmal contact, cleavage tends to parallel the regional schistosity (i.e., S2) observed in the lower unit (Figure 10a,b). The dip of S2 changes from $\sim 80^{\circ}$ to the north at the top of the upper unit, to $40 \mathrm{~N}$ a few hundred meters from the contact and it becomes subhorizontal towards the contact (Figures $8 \& 11$ ). This S2 schistosity corresponds to the primary regional fabric in the remainder of the upper unit and is parallel to the main regional schistosity S2 described in the lower unit (compare stereograms from Figures $2 b$ and $5 b$ ), forming one single fabric from the top to the bottom of the exposed crust (Figures 8 \& 11). S2 bears a steeply plunging stretching lineation L2 marked by quartz aggregates or recrystallized calcite ribbons in limestones. In domains of shallowly dipping schistosity - i.e. near the Puigmal contact - L2 has a N-S to NNW-SSE trend (Figure 5). Near the contact, meter-size folds have deformed carbonates and schists (Fig. 10). Associated with these folds, reverse faults showing top-to-the-south displacement seem to merge into the flat basal contact between the Puigmal and Núria-Canigou units (Fig. 10).

Figure 11 here

\subsection{Late deformation}

\subsubsection{Crenulation of regional schistosity}


In the upper and lower units, the primary schistosity (S2) was crenulated during late deformation. Crenulation lineations trend WNW-ESE (Figure 5). Although crenulation can be seen in all lithologies, it preferentially affects the micaschists and fine-grained leucocratic orthogneiss (Carança gneisses) at the top of the gneiss dome (Figure 6f). Strain was not strong enough to form a new regional schistosity during this stage but it is present as centimeter to millimeter-scale crenulation folds with E-W axes and vertical axial planes (Figure 7b). In some places, L2 is reoriented parallel to this new fabric or is partially obliterated, suggesting local strain localization within narrow zones.

On a larger scale, this late folding phase produced kilometer-scale open folds with E-W fold axes and vertical axial planes, parallel to the main axis of the Canigou gneiss dome (Figures $2 \mathrm{~b}$ and $5 b$ ). These folds may have generated the folding of the contact and the amplified dome shape (i.e. the vertical or overturned southern limb of the gneiss dome, see Figure 8). Because these late folds are crosscut by the normal and reverse faults described below, we propose that they are late Variscan in age and can be called F3, as proposed by Laumonier et al., (2010). This crenulation must not be confused with the crenulation cleavage observed in the western Axial Zone affecting the post-Variscan cover, which is indisputably Alpine in age (e.g., Müller and Roger, 1977, Izquierdo-Llavall et al. 2013; Rodríguez-Méndez et al. 2013, Cochelin et al. 2017).

\subsubsection{Post-Variscan faulting}

The entire Canigou massif is affected by several steeply dipping late normal faults, which are everywhere associated with quartz veins of thicknesses between $50 \mathrm{~cm}$ and $30 \mathrm{~m}$. These faults, which can have vertical offsets of hundreds of meters, affect both the orthogneiss and micaschist within the gneiss dome (Figures 8 and 12). The late Carboniferous Costabonne granite, which was not deformed during the three events described above, experienced only the 
development of 10 to 20 meter scale greenschist facies mylonites, as described by Casas (1982, 1986), as a result of this normal faulting. In several places, the Puigmal contact is concealed by late faults that are (i) normal faults associated with quartz veins, and (ii) reverse faults that are Alpine in age (Laumonier et al., 2015). Thus, these normal faults postdate the emplacement of the Costabonne granite and are shifted or reworked during Alpine thrusting. These faults were later cut by Neogene normal faults (e.g., the Têt fault) (see geologic maps of the Mont-Louis and Prades area, Autran, 1986; Guitard et al., 1992). On the basis of these observations, the early set of normal faults should be Permian in age (Laumonier et al., 2015) as proposed for the western Axial Zone (e.g., Rodríguez-Méndez et al. 2016) or alternatively, Cretaceous in age.

Figure 12 here

\section{Discussion}

4.1 Nature, tectonic significance of the South Canigou Shear Zone and local implications

\subsubsection{Nature of the contact}

The structural continuity between the schistosity along the Puigmal contact, the schistosity within the upper unit and the primary schistosity of the lower unit (S2) (Figures $9 \& 11$ ) lead us to interpret these structures as contemporaneous, that is formed during the same tectonic episode. The primary and regional schistosity in the upper unit, which is axial plane of recumbent to open folds, is thus contemporaneous with the activity/activation of the Puigmal contact. This contact is part of the SCSZ because forms the top of the shear zone where brittleductile deformation was localized (Figures 9 and 11). The top of the Canigou gneiss dome, i.e., the upper transition between orthogneiss and micaschists, is thus characterized by a high strain zone, the SCSZ. Although the protoliths of the Canigou and Núria orthogneisses were initially 
intruded within metasedimentary rocks, the Variscan mylonitization observed at this contact totally reworked the early historical link to the Ordovician intrusion. These new observations do not support the model proposed by Barbey et al., (2001) that proposes that the magmatic contacts of the Ordovician laccolith were remnants of the Variscan deformation. They reported examples of a metamorphic stage prior to the development of the main regional schistosity and interpreted them to be the result of contact metamorphism of the Ordovician intrusion. Based on our structural observations and the lack of contact metamorphism evidence, these relics more likely form the witnesses of a first Variscan metamorphic stage during hypothetical thickening, as proposed by Laumonier and Autran (2001), probably as a result of southwestward or westward thrusting (Cochelin et al., 2017). Nevertheless, except within the Balatg micaschists (De Hoÿm de Marien et al., 2019), this first Variscan event is almost completely obliterated throughout the entire Canigou massif, thus preventing better identification of early macro to microstructures and the strain regime and precluding an interpretation of the real significance of this previous event.

\subsubsection{Tectonic significance of the South Canigou Shear Zone}

According to Laumonier and Autran (2001), the Puigmal contact corresponds to a Variscan south-verging thrust. However, this interpretation is not supported by our structural and petrological observations. First, the regional stretching direction in the lower unit and the SCSZ is primarily E-W (e.g., in Núria area) to NE-SW, which is hardly compatible with southward thrusting. Second, the shear band kinematics observed within the SCSZ and the lower unit, which are consistent with microstructures, always correspond to a downdip sense of shear, mainly with a top-to-the-W or SW kinematics. Third, our petrological observations highlight/show that deformation occurred under retrogressive conditions, which is not compatible with thrusting and crustal thickening, which would record prograde metamorphism. As a result, we interpret the SCSZ as a single regional-scale extensional shear zone. In fact, this contact shows the 
juxtaposition of a low-grade metamorphic unit (Upper unit-Puigmal unit) with well-preserved stratigraphy on top of a metamorphic unit (Lower Unit-Núria Unit) defined by mylonitic andalusite or biotite micaschists and marble. A similar interpretation was made on the other side, on the northern flank of the Canigou gneiss dome, where Cochelin et al. (2017) reported a regional extensional shear zone synchronous with peak metamorphism.

\subsubsection{Implications for stratigraphy}

New geological mapping and structural data presented in this study raise questions about the previous lithostratigraphic characterization of the Puigmal area. Interpretation of the Puigmal tectonic contact (Laumonier and Autran, 2001) was based on an earlier lithostratigraphic model (Laumonier et al., 2004; Laumonier et al., 2015), in which the Puigmal contact is responsible for the truncation of lower Paleozoic sequences, inferred from the absence of the Cabrils formation between the Canaveilles and Evol formations. In our view, the metamorphism and strong deformation of the lower unit (i.e., the Núria Unit) rule out any correlation with the previous lithostratigraphy. Marble layers in the lower unit exhibit isoclinal folds, with no evidence of preserved bedding, and yet a pervasive schistosity has developed. No real constraint exists to assign these micaschists and marbles to the Canaveilles formation or the Nyer formation (Padel et al., 2018), which are supposed to be Ediacarian in age (Laumonier et al.,2015). The Canaveilles formation appears to be a tectonometamorphic unit rather than a lithostratigraphic unit because the Canaveilles has been described only within metamorphic gneiss domes in the western Axial Zone. Therefore, we suggest that the Canaveilles formation no longer be considered of Ediacarian age over the entire Axial Zone of the Pyrenees, or at least that extreme caution be taken in describing this formation in future studies.

\subsection{Synconvergence extension recorded in the Canigou gneiss dome}

\subsubsection{Tectonic history of the Canigou gneiss dome}


To explain the formation of the Canigou gneiss dome, we propose the following model

(Table 1 and Figure 13). After an early NE-SW or E-W convergence phase D1 responsible for Barrovian metamorphism (M1) and formation of recumbent folds in the upper crust (Figure 13a), the middle crust was affected by HT-LP metamorphism (M2a). In response to N-S convergence, this metamorphism induced E-W to NE-SW directed longitudinal crustal flow of the entire metamorphic pile with dominant top-to-the-west to southwest shearing during the D2a stage (Figure 14b). Within the Canigou gneiss dome, the stretching direction during longitudinal crustal flow follows a NE-SW trend, coupled to/with a divergent pattern from the core to the limbs of the domal structure. At the scale of the Canigou dome, the divergence of the stretching direction can be considered to be a second-order variation because most stretching lineations are strictly NE-SW (see Cochelin et al., 2018b, Figure 2b). We interpret this pattern to be the result of exhumation beginning in the middle crust and the development of domal geometry, highlighted by a downdip sense of shear associated with penetrative shear planes at peak metamorphism (i.e., M2a). At the same time, the upper crust was subjected to regional-scale folding with the formation of steep E-W axial plane cleavage (Figure 13b). Exhumation of the metamorphic pile was enhanced by strain localization within a regional-scale shear zone similar to the SCSZ, located at the limbs of the nascent gneiss dome. The stretching direction during strain localization (D2b) remained similar to the previous stage, with E-W to NE-SW trends at the top of the dome and in its core, to approximately N-S trends at the southern and northern limbs of the dome (Figure 13b). The progressive exhumation of the rising hot crust is shown by retrogressive paragenesis within the shear zones. Ultimately, strain was localized at the top of the regional shear zone (i.e. at the biotite-chlorite transition), forming the Puigmal contact, which shows kinematics similar to the SCSZ (Figure 13c). In the upper crust, regional folds and steep cleavage are amplified and flattened towards the Puigmal contact. Locally steep south-verging thrusts merged at the transition between the upper crust and the Puigmal contact, compatible with N-S horizontal shortening as recorded in the remainder of the upper crust (Figure 2b). The 
progressive cooling of the entire crust, still under N-S horizontal shortening, induced large scale folding of earlier structures (e.g., the Canigou dome and the Puigmal contact) due to increased coupling within the crust. This later stage (D3), called the "doming phase" (see Denèle et al., 2014) is responsible for the amplification of the dome shape, the folding of the SCSZ, and crenulation of the S2 regional schistosity (Figure 13d).

Table 1 here

\subsubsection{Mechanism of dome formation in the Variscan Pyrenees}

Although gneiss domes in the Axial Zone resemble folds (e.g., the Canigou gneiss dome), a detailed structural and petrological study shows that the dome shape does not result from fold interference but rather by ductile deformation at the upper-middle crust transition. In our model, we propose that the Canigou gneiss dome is an "a-type" gneiss dome (Jolivet et al., 2004) formed in response to lateral horizontal flow of the middle crust at ca. $310-290 \mathrm{Ma}$. The reasons are as follows:

(1) Extension and strain localization were observed at the top of the gneiss dome.

(2) The deformation recorded in the SCSZ during D2 is retrogressive, in agreement with PT calculations by de Hoÿm de Marien (2019), who suggest exhumation of the lower unit from 6 to 3 kbar during this tectonic phase.

(3) Stretching lineations are primarily parallel to the elongation of the gneiss dome, which is typical of "a-type" dome morphology (see Jolivet et al., 2004). Furthermore, evidence of N-S horizontal shortening (i.e., orthonormal to the direction of stretching in the lower crust) during the formation of the Canigou dome suggests constriction, which is commonly invoked to explain the formation of "a-type" domes. 
The ascent of the deeper rocks leading to the formation the Canigou dome was probably favored by gravity instabilities within the partially molten middle crust as a result of HT metamorphism between 310 and 290 Ma (Denèle et al., 2014; Lemirre et al., 2019). Indeed, HT metamorphism coupled with the melt accumulation near the brittle-ductile transition induces a strong rheological contrast between the two domains (Chardon et al. 2009). Affected by such instabilities, the weak and low buoyant middle crust tends to rise, assisted by strain localization within the rheological boundary, which acts as an extensional shear zone or a detachment fault (Vanderhaeghe and Teyssier 2001). Divergence of stretching lineations from the core to the limbs may reflect progressive exhumation of the buoyant and partially-molten middle crust, as in other "a-type" gneiss domes (Jolivet et al., 2004; Augier et al., 2005; Le Pourhiet et al., 2012; Cochelin et al., 2018b; Saspiturry et al., 2019). In the study area, this rheological contrast is illustrated by strain localization immediately above the orthogneiss, i.e., within micaschistmarble layers. The model of exhumation of deep crustal rocks favored by extensional shear zones that we propose here is contradicts models proposed by Guitard (1970); Soliva et al. (1989), Laumonier and Autran, (2001), Denèle et al., (2009) and Aguilar et al., (2015) in the eastern Pyrenees; these authors contend that exhumation is mainly controlled by folding and thrusting. The presence of extensional shear zones at the roof of nascent gneiss domes is well known in the Axial Zone, as described previously in the Hospitalet dome (Van den Eeckhout, 1986; Van den Eeckhout and Zwart, 1988), Bossòst dome (Mezger and Passchier, 2003), and more recently in the Bossòst, Lys-Caillaouas, Chiroulet, and Lesponne massifs (Cochelin et al. 2017, Lemirre et al., 2019). Within these domes, strain localization occurred mainly between Ordovician orthogneiss and their country rocks and/or within the andalusite-in isograd, as in the Canigou gneiss dome.

In the study area, primary deformation (D2) is compatible with regional EW to NE-SW extension. In the Pyrenees, most of the known extensional shear zones have been described in 
494

495

496

497

498

499

500

501

502

503

504

505

506

507

508

509

510

511

512

513

514

515

516

517

the North Pyrenean massifs. In fact, south-verging detachment faults compatible with crustal thinning during early to mid-Permian times have been observed in the Saint Barthélémy, the Agly or the Ursuya massifs (e.g., de Saint Blanquat, 1993; Olivier et al., 2004, Saspiturry et al., 2019). The latter was recently interpreted as an E-W-elongated "a-type" metamorphic core complex (Saspiturry et al., 2019), quite similar to the Canigou dome. Therefore, the extensional phase recorded in the Canigou dome may reflect the final exhumation stage of the middle crust under dominant vertical thinning and horizontal stretching, as observed in the North Pyrenean massifs.

Alternatively, the following observations may suggest that extension recorded in midcrustal rocks at the Canigou occurred in Late Carboniferous time, under transpressional conditions:

(1) Continuous fabrics from the lower unit to the upper unit, the latter characterized by folds oriented $\mathrm{N} 100^{\circ}$, steeply dipping axial plane cleavage, and steep stretching lineations. These steep lineations are associated with reverse-dextral kinematics throughout the entire Axial Zone (Fig. 2b; see Cochelin et al., 2018a,b).

(2) The activation of south-verging thrusts locally within the Puigmal contact, coupled with the folding of the SCSZ and the gneiss dome parallel to its elongation, which are both compatible with N-S horizontal shortening.

This interpretation is also supported by [available] geochronological data. The S2 fabrics observed in the Canigou dome were probably formed at ca. $305 \mathrm{Ma}$, the age of the youngest magmatic rocks affected by D2 (Denèle et al., 2014) and the age obtained on syn-D2 metamorphic minerals (de Hoÿm de Marien et al., 2019). The S2 fabric does not affect the Costabonne granite, which intruded the Canigou dome at ca. $302 \mathrm{Ma}$ (Laumonier et al., 2015)). This interpretation is consistent with previous work characterizing gneiss domes, plutons, and 
upper crustal rocks in the Axial Zone of the Pyrenees (Denèle et al., 2014; Cochelin et al., 2017 and references therein).

Under transpressional conditions, rocks within gneiss domes experience only limited exhumation, likely because the cold upper crust is not affected by significant vertical movement, which does not favor the formation of a topographic load at the origin of a syntectonic, flexural sedimentary basin (Cochelin et al. 2017). Here we have an examples of a limited exhumation with an estimated exhumation at approximately 2-3 kbar in the Canigou dome, significantly less exhumation than what is recorded in North Pyrenean massifs (i.e., from 6 to 2 kbar, see Saspiturry et al., 2019 and reference therein). Thus, crustal flow within the middle crust as recorded in the Canigou and other Axial Zone domes is mainly lateral (i.e. orthogonal to NS horizontal shortening) under N-S convergence.

Figure 13 here

\section{Conclusion}

Our structural study of the southwestern part of the Canigou-Núria gneiss dome leads us to propose a new tectonic model for gneiss dome emplacement (Table 1 and Figure 13). In our three-stage model, the primary schistosity within the Canigou dome formed during the D2 deformation phase, which is coeval with LP-HT metamorphism (M2) and plutonism at ca 310$290 \mathrm{Ma}$. S2 schistosity reworked an earlier S1 fabric that is preserved only as sparse relics. A third deformation phase caused late large-scale folding of the $S 2$ foliation.

On the basis of our work, we argue that the dome shape of the Canigou massif developed during the main tectonometamorphic (D2-M2) event, as a result of the activation of a retrogressive extensional shear zone located at the top of the gneiss dome. This extensional shear zone highlights the transition between the weak middle crust and the upper crust. We 
propose that the Canigou gneiss dome is an "a-type" gneiss dome that formed in response to

542 lateral horizontal flow of the middle crust during Late-Variscan transpression.

543 This model is not consistent with previous models that characterize the Canigou gneiss dome

544 as a recumbent fold, an Ordovician laccolith essentially undisturbed by Variscan deformation, or 545 the result of late Variscan folding during convergence.

\section{Acknowledgements}

This project was supported by the Bureau de Recherche Géologique et Minière (BRGM) through the Programme de la carte géologique de France with mapping of the Prats de Mollo at 1/50 000 scale sheet, and the Référentiel Géologique de la France program (RGF). We appreciate the fruitful discussions with T. Baudin, F. Cagnard, M. Padel, C. Gumiaux, J. Van den,Driessche, B. Laumonier, Y. Denèle, D. Chardon in the lab and in the field. We acknowledge M. Alleki for production of thin sections. We thank Patricia Bobeck (DBA Geotechnical Translations) for English revision of this manuscript.

\section{References}

Aguilar, C., Liesa, M., Castiñeiras, P., Navidad, M., 2014. Late Variscan metamorphic and magmatic evolution in the eastern Pyrenees revealed by U-Pb age zircon dating. Journal of Geological Society, London, 171(2), 181-192. doi: 10.1144/jgs2012-086.

Aguilar C., Liesa M., Štípská P., Schulmann K., Muñoz J.A., Casas J.M. 2015. P-T-t-d evolution of orogenic middle crust of the Roc de Frausa Massif (Eastern Pyrenees): a 
result of horizontal crustal flow and Carboniferous doming? J Metam Geol 33: 273-294. doi:10.1111/jmg.12120.

Augier R., Jolivet, L., Robin, C., 2005. Late Orogenic doming in the eastern Betic Cordilleras : Final exhumation of the Nevado-Filabride complex and its relation to basin genesis. Tectonics 24 : TC4003. doi:10.1029/2004TC001687:

Autran, A. 1986. Carte géologique de France (1/50 000), feuille de Mont-Louis (1094). Edition BRGM, Orléans, France.

Autran, A., Guitard, G., 1969. Mise en évidence de nappes hercyniennes de style pennique dans la série métamorphique du massif du Roc-de-France (PyrénéesOrientales). C. R. Acad. Sci., Paris, 263, II, 317-320.

Azambre, B., Guitard, G., 2001. Disthène et staurotide reliques dans les métapélites du Canigou (Pyrénées orientales). Relations avec les épisodes hercyniens de basse et moyenne pressions. Comptes rendus de l'académie des Sciences. 333. 601-609.

Barbey, P., Cheilletz, A., Laumonier, B., 2001. The Canigou orthogneisses (Eastern Pyrenees, France, Spain): an early Ordovician rapakivi granite laccolith and its contact aureole. Comptes rendus de l'académie des Sciences. Ser. II. 332(2). 129-136. doi: $10.1016 / \mathrm{S} 1251.8050(00) 01506-8$.

Bodin, J. and Ledru, P., 1986. Nappes hercyniennes précoces à materiel dévonien hétéropique dans les Pyrénées ariégeoises, C. R. Acad. Sci., Sér. 2, 302, (15), 969974. 
582

583

584

585

586

587

588

589

590

591

592

593

594

595

596

597

598

599

600

601

602

Bouchez, JL, Gleizes, G. 1995. Two-stage deformation of the Mont- Louis-Andorra granite pluton (Variscan Pyrenees) inferred from magnetic susceptibility anisotropy. J Geol Soc 152: 669-679. doi: 10.1144/gsjgs.152.4.0669.

Burg, J-P, Van den Driessche, J, Brun, J-P., 1994. Syn- to post-thickening extension in the Variscan Belt of western Europe: modes and structural consequences. Géologie de la France, 33-51.

Brun, J.-P., 2002, Deformation of the continental lithosphere: Insights from brittle-ductile models, Geol. Soc. London, Spec. Publ., 200(1), 355-370. doi:10.1144/GSL.SP.2001. 200.01.20.

Casas, J. M., Castiñeiras, P. Navidad, M., Liesa, M., Carreras, J., 2010. New insights into the Late Ordovician magmatism in the Eastern Pyrenees: U-Pb SHRIMP zircon data from the Canigo massif. Gondwana Research 17. 317-324. doi: 10.1016/j.gr.2009.10.006.

Carreras J, Capella I. 1994. Tectonic levels in the Palaeozoic basement of the Pyrenees: a review and a new interpretation. J Struct Geol 16: 1509-1524. doi: 10.1016/0191-8141(94)90029-9.

Casas, J.M. 1982. Pseudo-two-girdles c-axis fabric patterns in a quartz-feldspar mylonite (Costabona granodiorite, Canigó massif). Acta Geológica Hispánica, 17 (3), 151-157.

Casas, J.M. 1986. Shear bands and related extensional structures in a mylonitized quartz Dyke. Journal of Structural Geology, 8 (6), 693-699. 
603

604

605

606

607

608

609

610

611

612

613

614

615

616

617

618

619

620

621

622

Casas, J. M., Castiñeiras, P., Navidad, M., Liesa, M., Carreras, J., 2010. New insights into the Late Ordovician magmatism in the Eastern Pyrenees: U-Pb SHRIMP zircon data from the Canigo massif. Gondwana Research 17: 317-324. doi:10.1016/j.gr.2009.10.006.

Castiñeiras, P., Navidad, M., Liesa, M., Carreras, J., Casas, J. M., 2008. U-Pb zircon ages (SHRIMP) for Cadomian and Early Ordovician magmatism in the Eastern Pyrenees: New insights into the pre-Variscan evolution of the northern Gondwana margin. Tectonophysics 461. 228-239. doi: 10.1016/j.tecto.2008.04.005.

Chardon, D., D. Gapais, and F. Cagnard, 2009. Flow of ultra-hot orogens: A view from the Precambrian, clues for the Phanerozoic, Tectonophysics, 477(3-4), 105-118. doi:10.1016/j.tecto.2009.03.008.

Choukroune, P. 1992, Tectonic evolution of the Pyrenees, Annu. Rev. Earth Planet. Sci., 20,143 .

Cochelin, B., Chardon, D., Denèle, Y., Gumiaux, C., Le Bayon, B., 2017. Vertical strain partitioning in hot Variscan crust: Synconvergence escape of the Pyrenees in the Iberian-Armorican syntax, Bull. Soc. géol. Fr. 188: 39. doi: 10.1051/bsgf/2017206.

Cochelin, B., Lemirre, B., Denèle, Y., de Saint Blanquat, M., Lahfid, A., Duchêne, S., 2018a. Structural inheritance in the Central Pyrenees: the Variscan to Alpine tectonometamorphic evolution of the Axial Zone. Journal of the Geological Society, London, Vol. 175, 336-351. doi:10.1144/jgs2017-066. 
623

624

625

626

627

628

629

630

631

632

633

634

635

636

637

638

639

640

641

642

Cochelin, B., Gumiaux, C., Chardon, D., Denèle, Le Bayon, B., 2018b. Multi-scale strainfield analysis using geostatistics: Investigating the rheological behavior of the hot Variscan crust of the Pyrenees (Axial Zone). Journal of structural Geology, 116, 114130. doi:10.1016/j.jsg.2018.07.024

Cocherie, A., Baudin, Th., Autran, A., Guerrot, C., Fanning, C.M., Laumonier, B., 2005. U-Pb zircon (ID-TIMS and SHRIMP) evidence for the early Ordovician intrusion of metagranites in the late Proterozoic Canaveilles Group of the Pyrenees and the Montagne Noire (France). Bull. Soc. Géol. Fr. 176, 269-282.

De Hoÿm de Marien, L., Le Bayon, B., Pitra, P., Van Den Driessche, J., Poujol, M., Cagnard, F., 2019. Two-stage Variscan metamorphism in the Canigou massif: Evidence for crustal thickening in the Pyrenees. J Metamorph Geol. 37; 863-888. doi:10.1111/jmg.12487

Deloule, E., Alexandrov, P., Cheilletz, A., Laumonier, B., Barbey, P., 2002. In-situ U-Pb zircon ages for Early Ordovician magmatism in the eastern Pyrenees, France: the Canigou orthogneisses. Int. J. Earth Sci. 91, 398:405.

Denèle, Y., Olivier, P., Gleizes, G., Barbey, P., 2007. The Hospitalet gneiss dome (Pyrenees) revisited: lateral flow during Variscan transpression in the middle cruste. Terra Nova 19 (6), 445-453. doi: 10.1111/j.1365-3121.2007.00770.x.

Denèle, Y., Olivier, P., Gleizes G., 2008. Progressive deformation of a zone of magma transfer in a transpressional regime: The Variscan Mérens shear zone (Pyrenees, 
643 France). Journal of structural geology. 30(9). 1138-1149. doi: $644 \quad 10.1016 /$ j.jsg.2008.05.006.

645 Denèle, Y., Olivier, P., Gleizes, G., Barbey, P., 2009. Decoupling between the middle 646 and upper crust during transpression-related lateral flow: Cariscan evolution of the 647 Aston gneiss dome (Pyrenees, France). Tectonophysics 477 (3-4), 244-261. doi: 648 10.1016/j.tecto.2009.04.033.

Denèle Y, Laumonier B, Paquette JL, Olivier P, Gleizes G, Barbey P. 2014. Timing of 650 granite emplacement, crustal flow and gneiss dome formation in the Variscan segment 651 of the Pyrenees. Geol Soc Spec Publ 405: 265-287. doi: 10.1144/SP405.5.

652 Denèle, Y., Roques, D., Ganne, J., Chardon, D., Rousse, S., Barbey, P., 2017. Strike653 slip metamorphic core complexes: Gneiss domes emplaced in releasing bends. The 654 Geological Society of America. doi:10.1130/G39065.1

655 Delvolvé, JJ, Souquet, P., Vachard, D., Perret, MF., Aguirre P., 1993. Caractérisation 656 d'un bassin d'avant-pays dans le Carbonifère des Pyrénées: faciès, chronologie de la 657 tectonique synsédimentaire. C R Acad Sci 316: 959-966.

658 Druguet, E., 2001. Development of high thermal gradients by coeval transpression and 659 magmatism during the Variscan orogeny: insights from the Cap de Creus (Eastern 660 Pyrenees). Tectonophysics, 332, 1-2, p 275-293.

661 Druguet E, Castro A, Chichorro M, Pereira MF, Fernández C. 2014. Zircon 662 geochronology of intrusive rocks from Cap de Creus, Eastern Pyrenees. Geol Mag 151: 663 1095-1114. doi: 10.1017/ S0016756814000041. 
664

665

666

667

668

669

670

671

672

673

674

675

676

677

678

679

680

681

682

683

684

Esteban, JJ, Aranguren, A., Cuevas, J., Hilario, A., Tubía., JM., Larionov, A., 2015. Is there a time lag between the metamorphism and emplacement of plutons in the Axial Zone of the Pyrenees? Geol Mag 152: 935-941. doi: 10.1017/S001675681500014X.

Faure, M., Lardeaux, J-M., Ledru, P., 2009. A review of the pre-Permian geology of the French Massif Central. C. R. Geoscience, 341, pp. 202-213.

Franke, W., Doublier, M. P., Klama, K., Potel, S., \& Wemmer, K., 2011. Hot metamorphic core complex in a cold foreland. International Journal of Earth Sciences, 100, 753-786.

Gapais D., Brun J.-P., Gumiaux C., Cagnard F., Ruffet G., Le Carlier de Veslud C. 2015. Extensional tectonics in the Hercynian Armorican belt (France). An overview. Bull Soc Géol Fr 186: 117-129. doi:10.2113/gssgfbull.186.2-3.117.

Geyssant, J., Grandjacquet, C., Guitard, G., 1978. La terminaison de la nappe des gneiss du Canigou au nord-est du massif du Roc de France (Pyrénées orientales) et ses replissements tardifs. Comptes rendus de l'académie des Sciences. Ser. D. 287. 1187-1190.

Gibson, R. L., 1991. Hercynian low-pressure-high-temperature regional metamorphism and subhorizontal schistosity development in the Canigou massif, Pyrenees, FranceEvidence for crustal extension. Geology. 19(4). 380-383, doi: 10.1130/00917613(1991)019<0380:HPLPHTR>2.3.CO;2.

Gibson, R. L., Bickle, M. J. 1994. Thermobarometric constraints on the conditions of metamorphism in the Canigou massif, Pyrenees: implications for Hercynian geothermal 
685

686

687

688

689

690

691

692

693

694

695

696

697

698

699

700

701

702

703

704

gradients. Journal of the Geological Society of London. 151(6). 987-997, doi: 10.1144/gsjgs.151.6.0987.

Gleizes G, Leblanc D, Bouchez JL. 1998. The main phase of the Hercynian orogeny in the Pyrenees is a dextral transpression. Geol Soc Spec Publ 135: 267-273. doi: 10.1144/GSL.SP.1998.135.01.17.

Gretter, N., Ronchi, A., López-Gómez, J., Arche, A., De la Horra, R., Barrenechea, J., Lago, M., 2015. The late Palaeozoic-early Mesozoic from the Catalan Pyrenees (Spain): $60 \mathrm{Myr}$ of environmental evolution in the frame of the western peri-Tethyan palaeogeography. Earth Sci. Rev., 150, pp.679-708, doi: 10.1016/j.earscirev.2015.09.001.

Guitard, G. 1953. La structure du massif du Canigou. Bulletin Societé Géologique de France 3, 907-924.

Guitard, G. 1967. Phases de plissement dans les terrains métamorphiques de la zone axiale pyrénéenne du Canigou durant l'orogenése hercynienne. Comptes Rendus Académie Sciences Paris 265, 1357-1360

Guitard, G. 1964. Un exemple de structure en nappe de style pennique dans la chaîne hercynienne : les gneiss stratoïdes du Canigou (Pyrénées Orientales), C. R. Acad. Sci. Ser. II, 258, 4597-4599.

Guitard, G., 1970. Le métamorphisme hercynien mésozonal et les gneiss oeillés du massif du Canigou (Pyrénées-Orientales). BRGM. Mém. 63, 353 pp. 
Guitard, G., Geyssant, J., Laumonier, B., Autran, A., Fonteilles, M., Dalmayrach, B., Vidal, J-C., Bandet, Y., 1992. Carte géologique de France $(1: 50$ 000). Feuille de Prades (1095). Edition BRGM, Orléans, France. Notice explicative par G. Guitard et al., (1998), 198p.

Guitard G, Vielzeuf D, Martinez F. 1996. Métamorphisme hercynien. In Synthèse Géologique et Géophysique Des Pyrénées vol. 1. Orléans (France) : BRGM-ITGE, pp. $501-584$.

Izquierdo-Llavall, E., Casas-Sainz, A.M., Oliva-Urcia, B. 2013. Heterogeneous deformation recorded by magnetic fabrics in the Pyrenean Axial Zone. Journal of Structural Geology, 57, 97-113, doi: 10.1016/j.jsg.2013.10.005.

Jolivet, L., Famin, V., Mehl, C. et al., 2004. Strain localization during crustal-scale boudinage to form extensional metamorphic domes in the Aegean Sea. In: Gneiss Domes in Orogeny (eds Whitney, D., Teyssier, C. \& Siddoway, C. S.), pp. 391. Special Paper, The Geological Society of America, Boulder, USA.

Kilzi, M. A., Grégoire, M., Bosse, V., Benoît, M., Driouch, Y., de Saint Blanquat, M. Debat, P., 2016. Geochemistry and zircon U-Pb geochronology of the ultramafic and mafic rocks emplaced within the anatectic series of the Variscan Pyrenees: The example of the Gavarnie-Heas dome (France), Comptes Rendus Geoscience, 348(2), p107-115. doi: 10.1016/j.crte.2015.06.014.

Lagarde J.-L., 1978. La déformation des roches dans les domaines à schistosité subhorizontale. Application à la nappe du Canigou-Roc de France (Pyrénées 
orientales) et au complexe cristallophyllien de Champtoceaux (Massif armoricain), $\mathrm{PhD}$ thesis, Univ. Rennes, France.

Lagarde, J-L., and Millot, G., 1978. Analyse du sens de déversement d'une nappe gneissique. Application à la nappe hercynienne du Canigou (Pyrénees Orientales). Comptes rendus de l'académie des Sciences. Sér. D. 286. 937-940.

Laumonier, B., Autran, A., 2001. Un chevauchement hercynien majeur dans les Pyrénes orientales : le chevauchement du Puigmal. Comptes rendus de l'académie des Sciences. Ser. IIA. 332(9). 585-594, doi : 10.1016/S1251-8050(01)01569-5.

Laumonier, B., Autran, A., Barbey, P., Cheilletz, A., Baudin, T., Cocherie, A., Guerrot, C., 2004. Conséquences de l'absence de socle cadomien sur l'âge et la signification des séries pré-varisques (anté- Ordovicien supérieur) du sud de la France (Pyrénées, Montagne Noire). Bull Soc géol Fr 175:105-117.

Laumonier, B., Barbey, P., Denèle, Y., Olivier, P., Paquette J.-L., 2014. Réconcilier les données stratigraphiques, radiométriques, plutoniques, volcaniques et structurales au Pennsylvanien supérieur (Stéphanien - Autunien p.p.) dans l'Est des Pyrénées hercyniennes (France, Espagne). Rev. Géol. pyrén., 1, 2, 10 p.

Laumonier, B., C. Marignac, and P. Kister, 2010. Polymétamorphisme et évolution crustale dans les Pyrénées orientales pendant l'orogenèse varisque au Carbonifère supérieur, Bull. Soc. Géol. Fr., 181(5), 411-428. 
Laumonier, B., Le Bayon, B., Calvet, M., 2015. Carte géologique France (1/50 000), feuille Prats-de-Mollo-La-Preste (1099). Orléans: BRGM. Notice explicative par Laumonier, B., Calvet, M., Le Bayon, B., Barbey, P., Lenoble, J.-L., 2015, 189p.

Ledru P., Courrioux, G., Dallain, C., Lardeaux, J.M., Montel, J.M., Vanderhaeghe, O., Vitel, G. 2001. The Velay dome (French Massif Central): melt generation and granite emplacement during orogenic evolution. Tectonophysics, 342, 207-227.

Lemirre, B., 2018. Origine et développement de la thermicité dans les Pyrénées varisques. PhD thesis, Univ. Paul Sabatier, Toulouse, France, 299p.

Lemirre, B., Cochelin, B., Duchene, S., de Saint Blanquat, M., Poujol, M., 2019. Origin and duration of late orogenic magmatism in the foreland of the Variscan belt (Lesponne-Chiroulet—Neouvielle area, French Pyrenees). Lithos, 336-337, 183-201. doi:1 0.1016/j.lithos.2019.03.037.

Le Pourhiet, L., Huet, B., May, D. A., Labrousse, L., Jolivet, L., 2012. Kinematic interpretation of the 3D shapes of metamorphic core complexes, Geochem. Geophys. Geosyst., 13, Q09002, doi:10.1029/2012GC004271.

Liesa M, Carreras J, Castiñeiras P, Casas JM, Navidad M, Vila M 2011. U-Pb zircon of Ordovician magmatism in the Albera Massif (Eastern Pyrenees). Geol Acta 9:93-101.

Lister, G.S., Banga, G., and Feenstra, A., 1984. Metamorphic core complexes of cordilleran type in the Cyclades, Aegean Sea, Greece: Geology, v. 12, p. 221-225. 
Lister G.S., Davis G.A., 1989. The origin of metamorphic core complexes and detachment faults formed during Tertiary continental extension in the northern Colorado River region, U.S.A. Journal of Structural Geology, 11: 65-94.

Lopez-Sanchez, M.A., García-Sansegundo, J., Martínez, F.J. (2018). The significance of early Permian and early Carboniferous $\mathrm{U}-\mathrm{Pb}$ zircon ages in the Bossòst and LysCaillaouas granitoids (Pyrenean Axial Zone). Geological Journal, 1-16. https://doi.org/10.1002/gj.328

Losantos, M., Palau, J., Stanz, J., 1986. Considerations about hercynian thrusting in the Marimanya massif (Central Pyrenees), Tectonophysics, 129(1), 71-79, doi : 10.1016/00401951(86)90246-5.

Martinez, F.J., Iriondo, A., Aleinikoff, J.N., Peucat, J.-J., Cires, J. \& Dietsch, C. 2010. U$\mathrm{Pb}$ SHRIMP zircon ages and Nd signature of Variscan basement, eastern Pyrenees (France) and Catalan Coastal Ranges (Spain): rift-related granitoids above cryptic Cadomian basement. GSA Ann. Meeting., paper 98-15.

Matte, P., Lancelot, J., Mattauer, M., 1998. La zone axiale hercynienne de la Montagne Noire n'est pas un "metamorphic core complex" extensif mais un anticlinal post-nappe à cœur anatectique, Geodinamica Acta, Volume 11, Issue 1, Pages 13-22, ISSN 09853111. doi : 10.1016/S0985-3111(98)80025-9.

Maurel, O., Respaut, J-P., Monié, P., Arnaud, N., Brunel, M. 2004. U-Pb emplacement and $40 \mathrm{Ar} / 39 \mathrm{Ar}$ cooling ages of the eastern Mont-Louis granite massif (Eastern Pyrenees, France). Comptes Rendus Geoscience, 336, 1091-1098. 
Mezger, J. E., 2009. Transpressional tectonic setting during the main Variscan deformation: evidence from four structural levels in the Bossòst and Aston-Hospitalet mantled gneiss domes, central Axial Zone, Pyrenees. Bulletin de la Société géologique de France. 180(3). 199-2017. doi: 10.02113/gssgfbull.180.3.199.

Mezger, J. E., Gerdes, A., 2016. Early Variscan (Visean) granites in the core of central Pyrenean gneiss domes: implications from laser ablation $\mathrm{U}-\mathrm{Pb}$ and $\mathrm{Th}-\mathrm{Pb}$ studies. Gondwana Research. 29, 1, p 181-198.

Mezger, J. E., Passchier, C. W., 2003. Polymetamorphism and ductile deformation of staurolite-cordierite schist of the Bossòst dome: indication for Variscan extension in the Axial Zone of the central Pyrenees. Geology Magazine 140(5). 595-612. doi: $10.1017 / \mathrm{S} 0016756803008112$.

Müller J., Roger P. 1977. L'Évolution structurale des Pyrénées (domaine central et occidental). Le segment hercynien, la chaîne de fond alpine. Géol. Alpine 2: 1-191.

Muñoz, J.A. 1992. Evolution of a continental colision belt:ECORS-Pyrenees crustal balanced cross-section. In Thrust Tectonics (ed K. R. Mc Clay), pp. 235-246.

Navidad M., Castiñeiras P., Casas J. M., Liesa M., Belousova E., Proenza J., Aiglsperger Th., 2018. Ordovician magmatism in the Eastern Pyrenees: Implications for the geodynamic evolution of northern Gondwana. Lithos, 314-315: 479-496

Olivier, P., Gleizes, G., Paquette, J-L., 2004. Gneiss domes and granite emplacement in an obliquely convergent regime: New interpretation of the Variscan Agly Massif (Eastern Pyrenees, France). Geological society of America, special paper 380, 229-242. 
807

808

809

810

811

812

813

814

815

816

817

Padel, M., Alvaro, J.J, Casas, J.M., Clausen, S., Poujol, M., 2017. Cadomian volcanosedimentary complexes across the Ediacaran-Cambrian transition of the Eastern Pyrenees, southwestern Europe, International Journal of Earth Sciences, 107: 1579-1601. doi:10.1007/s00531-017-1559-5.

Padel, M., Clausen, S., Alvaro, J.J., Casas, J.M., 2018. Review of the Ediacaran-Lower Ordovician (pre-Sardic) stratigraphic framework of the Eastern Pyrenees, southwestern Europe. Geologica Acta, vol.16, 4, 339-355. doi: 10.1344/GeologicaActa2018.16.4.1.

Perreira, M.F., Castro, A., Chichorro, M., Fernandez, C., Diaz-Alvarado, J., Marti, J., Rodriguez, C., 2014. Chronological link between deep-seated processes in magma chambers and eruptions: Permo-Carboniferous magmatism in the core of Pangaea (Southern Pyrenees). Gondwana Research, 25, 1, 290-308.

Poitrenaud, T., Poujol, M., Augier, R., Marcoux, E., 2019. The polyphase evolution of a late Variscan W/Au deposit (Salau, French Pyrenees): insights from REE and U/Pb LAICP-MS analyses. Miner Deposita 30, 111-128. doi:10.1007/s00126-019-00923-2.

Pouget, P., 1987. Le massif granitique de Lesponne (Haute Pyrénées): un exemple de massif plutonique hercynien à mise en place diapirique syncinématique. Geologische Rundschau, 76/1, 187-199.

Pouget, P., 1991. Hercynian tectonometamorphic evolution of the Bossost dome (French-Spanish Central Pyrenees), J. Geol. Soc. London, 148, 299-314, doi: 10.1144/gsjgs.148.2.0299. 
827

828

829

830

831

832

833

834

835

836

837

838

839

840

841

842

843

844

845

Rabin, M., Trap, P., Carry, N., Fréville, K., Cenki-Tok, B., Lobjoie, C., Goncalves, P., and Marquer, D., 2015. Strain partitioning along the anatectic front in the Variscan Montagne Noire massif (southern French Massif Central). Tectonics, 34(8), 1709-1735, doi:10.1002/2014TC003790.

Robert, J.F., 1980. Étude géologique et métallogenétique du val de Ribas sur le versant espagnol del Pyrénées Catalanes. PhD Thesis., Univ. Besançon, 294 pp. Roger, F., Teyssier, C., Respaut, J-P., Rey, P. F., Jolivet, M., Whitney, D. L., Paquette, J-L, Brunel, M., 2015. Timing of formation and exhumation of the Montagne Noire double dome, French Massif Central, Tectonophysics, 640-641,53-69, doi: 10.1016/j.tecto.2014.12.002.

Rodríguez-Méndez, L., Cuevas, J., Tubía, J.M. 2013. Geological map of the central Pyrenees between the Tena and Aragon valleys (Huesca), Journal of Maps, 9 (4), 596603, doi:10.1080/17445647.2013.839962

Rodríguez-Méndez, L., J. Cuevas, and J. M. Tubía, 2016. Post-Variscan basin evolution in the central Pyrenees: Insights from the Stephanian-Permian Anayet Basin, Comptes Rendus Geoscience, 348(3-4), 333-341, doi:10.1016/j.crte.2015.11.006.

Romer, R.L. and Soler, A. 1995. U-Pb age and lead isotopic characterization of Aubearing skarn related to the Andorra granite (central Pyrenees, Spain). Mineralium Deposita, 30, 374-383. 
de Saint Blanquat, M., Lardeaux, J-M., Brunel, M., 1990. Petrological arguments for high-temperature extensional deformation in the Pyrenean Variscan crust (Saint Barthélémy Massif, Ariège, France). Tectonophysics, 177, 245-262.

de Saint Blanquat, M., 1993. The ductile normal fault of the Saint Barthélémy Massif Variscan evolution of the north-pyrenean catazonal massifs considered from the viewpoint of their thermal history. Geodinamica Acta, 6:1, 59-77, doi: 10.1080/09853111.1993.11105239.

Santanach, P., 1972. Estudio tectónico del Paleozoico inferior del Pirineo entre la Cerdaña y el río Ter. Acta Geológica Hispánica 7, 44-49.

Saspiturry, N., Cochelin, B., Razin, P., Leleu, S., Lemirre, B., Bouscary, C., Issautier, B., Serrano, O., Lasseur, E., Baudin, T., Allanic, C., 2019. Tectono-sedimentary evolution of a rift system controlled by Permian post-orogenic extension and metamorphic core complex formation (Bidarray Basin and Ursuya dome, Western Pyrenees). Tectonophysics, 768, 228180. doi: 10.1016/j.tecto.2019.228180

Schnapperelle, S, Mezger, J.E., Stipp, M., Hofmann, M., Gärtner, A., Linnemann, U., 2020. Polyphase magmatic pulses along the Northern Gondwana margin: U-Pb zircon geochronology from gneiss domes of the Pyrenees. Gondwana Research, 18, 291-311. doi: 10.1016/j.gr.2019.11.013.

Sebastián, A., Martínez, F.J., Gil Ibarguchi, J.I., 1982. Petrología y geoquímica de los gneises de Queralbs-Núria (Provincia de Gerona). Boletín Geológico y Minero XCIIIVI, pp. $508-523$ 

Soliva, J., 1992. Les Déformations Ductiles Dans La Zone Axiale Des Pyrénées Orientales: la convergence varisque, la mise en place des granites tardi-hercyniennes, la convergence pyrénéenne, Thèse 3ème cycle, Univ. de Montpellier, France.

Soliva, J., Salel, J.L., Brunel, M., 1989. Shear deformation and emplacement of the gneissic Canigou thrust nappe, Eastern Pyrenees. Geologie Mijnbouw, 68, 357-366.

Soula, J. -C., 1982. Characteristics and modes of emplacement of gneiss domes and plutonic domes in central-eastern Pyrenees. Journal of structural geology. 4(3). 313342.

Soula, J. C., Debat, P., Deramond, J., Pouget, P.,1986. A dynamic model of the structural evolution of the Hercynian Pyrenees, Tectonophysics, 129(1), 29-51.

Tirel, C., Brun, J-P., Burov, E., 2008. Dynamics and structural development of metamorphic core complexes. J. Geophys. Res., 113, B04403, doi:10.1029/2005JB003694.

Vanardois, J., Trap, P., Goncalves, P., Marquer, D., Gremmel, J., Siron, G., and Baudin, T., 2020. Kinematics, deformation partitioning and late Variscan magmatism in the Agly massif, Eastern Pyrenees, France. BSGF - Earth Sciences Bulletin, 191, 15.

Van Den Driessche, J,. Brun, J-P., 1992, Tectonic evolution of the Montagne Noire (French Massif Central): a model of extensional gneiss dome, Geodin. Acta, 5(1-2), 8597,doi:10.1080/09853111.1992.11105221.

Van den Eeckout, B., 1986. A case study of a mantled gneiss antiform, the Hospitalet massif, Pyrenees (Andorra, France), Geol. Ultraiectina, 45, 1-189. 
888 Van den Eeckhout, B., Zwart, H. J., 1988. Hercynian crustal-scale extensional shear 889 zone in the Pyrenees, Geology, 16(2), 135-138, doi:10.1130/0091890 7613(1988)016<0135: HCSESZ>2.3.CO;2.

891 Vanderhaeghe O., Teyssier C., 2001. Partial melting and flow of orogens. 892 Tectonophysics 342: 451-472. DOI:10.1016/S0040-1951(01)00175-5.

893 Vilà, M., Pin, C., Liesa, M., Enrique, P., 2007. LPHT metamorphism in a late orogenic 894 transpressional setting, Albera Massif, NE lberia: implications for the geodynamic 895 evolution of the Variscan Pyrenees. Journal of metamorphic geology. 25(3). 321-347, 896 doi : 10.1016/0264-8172(95)98854-X.

897 Whitney, D.L, Teyssier, C., and Vanderhaeghe, O., 2004, Gneiss domes and crustal 898 flow, in Whitney, D.L, Teyssier, C., and Siddoway, C.S., Gneiss domes in orogeny: 899 Boulder, Colorado, Geological Society of America Special Paper 380.

900 Zwart HJ. 1979. The geology of the Central Pyrenees. Leidse Geol Meded 50: 1-74. 
Table 1. Summary of the deformation history of the southern Canigou gneiss dome.

Sources of petrological and geochronological data are acknowledged in the text.

906

907

908

Figure 1: Sketch map of the Variscan crust of the Pyrenees (Axial Zone). Location of figure 2 is shown. Ca stands for Canigou dome.

Figure 2. a) Simplified tectonic map of the Eastern Pyrenees. Shear senses measured on S2 schistosity are represented by black arrows. Location of the maps in figures 4 and 5 are shown. b) Stereograms of schistosity poles and stretching lineations in the middle and upper crust, extracted from the structural database from Cochelin et al., 2017, 2018b).

Figure 3. This figure synthetizes the primary earlier models used to explain Canigou dome emplacement (Barbey et al., 2001). A) The recumbent fold of Guitard (1970), the Balatg micaschists (at the base of the orthogneiss) are the equivalent of micaschists that overlie the orthogneiss, orthogneiss boundaries are interpreted as stratigraphic contacts; B) Canigou Nappe with mylonitic zones, orthogneiss boundaries are tectonic contacts (thrusts) with a top-to-the-southwest sense of shear (Lagarde, 1978; Soliva, 1992); C) Laccolith intrusion of Ordovician granites homogeneously deformed during Variscan orogeny, orthogneiss boundaries are interpreted as early intrusive contacts (Barbey et al., 2001). 
Figure 4. Geological map of the southwestern part of the Canigou massif. This map is a simplified map drawn on the basis of BRGM 1/50 000 sheets (Mont-Louis, Prats de Mollo). Map shows the location of the cross section in figure 5.

Figure 5. Structural data of the southwestern Canigou dome shown on (a) map and (b) stereograms, representing main phase schistosity S2, lineation L2, D3 crenulation fold axes, and shear sense.

Figure 6. Examples of various deformation patterns in the lower unit of the Puigmal tectonic contact.

a) Deformation in the Canigou orthogneiss from an outcrop located in the northwestern part of the dome (BLB1555, Cambre d'Ase). C' Shear bands and pressure shadows around Kfs porphyroclasts indicate a top to the W-NW sense of shear, with top-to-the-N295.

b) Deformation in the Canigou Orthogneiss (G1), E-W stretching lineation defined by aligned biotite and stretched quartz and feldspar.

c) Strain gradient in the orthogneiss. Mylonites in the Carança orthogneiss (Orri Valley; BLB1314-BLB1315), at the contact with metasediments (micaschists and marble of the Canaveilles formation). C' Shear bands and pressure shadows around Kfs porphyroclasts indicate a top-to-the-SSW sense of shear (top-to-theN2059.

d) Regional schistosity (S2) in micaschist (BLB1336) with shear bands oriented topto-the-N210 .

e) Isoclinal F2 folds in marble (BLB 1541) reworking an S0-1 fabric. 
f) Canaveilles micaschist/paragneiss (BLB1257, Nuría Valley). The main schistosity (S2) is crenulated with E-W fold axes (F3).

Figure 7. Photomicrographs of samples from the lower unit (Nuría-Canigou unit: PRA13b, 35a, 36a,39a, and 55a) and the upper unit (Puigmal unit: PRA47 and PRA48). a) Sillimanite-bearing (fibrolite patches) micaschists from the core of the dome; b) andalusite-staurolite-biotite micaschist with late chlorite growth; c) micaschist with helicitic garnet porphyroclast deformed by S2 schistosity; d) chloritized garnet and late chlorite-bearing shear bands; e) S2 schistosity defined by quartz-plagioclase-chloritized biotite paragenesis; f) chlorite growth in pressure shadow during retrograde metamorphism (M2b); g) low-grade mylonite at the Puigmal tectonic contact; h) folds and development of S2 schistosity in schists at the Puigmal tectonic contact.

Figure 8. Simplified S-N cross section (for location see figure 2). This cross section shows the Puigmal contact and the South Canigou Shear Zone at the southern boundary of the Canigou Dome. Metamorphic isograds are outlined in red.

Figure 9. Geological panorama of the northern flank of Coma del'Embut illustrating the contact of the Puigmal unit (Upper unit), consisting of abundant schists, with the Nuría unit (Lower unit) made up of biotite-bearing micaschists and highly deformed marble. Photos a,b, and c illustrate the deformation gradient towards the tectonic contact. a) Photograph of outcrop BLB1262: S0-1 is folded (crenulation folds), b) Photograph of outcrop BLB1384: development of S2 crenulation cleavage, and c) Photograph of outcrop BLB1383: black schists along the Puigmal tectonic contact. S2 (axial plane of folds) is parallel to and contemporaneous with the Puigmal tectonic contact. 
967

968

969

970

971

972

973

974

975

976

977

978

979

980

981

982

983

984

985

Figure 10. Geological panorama as seen from the hiking trail close to Fontalba towards the Puigmal peak.

a) Photograph of outcrop BLB1588: Puigmal tectonic contact between brecciated carbonates and schists. Sigmoids indicate a top-to-the-southwest sense of shear.

b) Photograph of outcrop BLB1587: brecciated carbonates.

c) And d) Photographs of outcrop BLB1589: highly deformed marble.

Figure 11. Simplified S-N cross section of the Coma del Embut showing the Puigmal tectonic contact and the deformation gradient, with development of S2 crenulation cleavage in the upper unit.

Figure 12. (a) This geological panorama was taken from the Bastiments summit and shows two late normal faults, with a quartz vein. The southern normal fault reveals the roof of the Canigou dome with marble and micaschist; (b) geological panorama taken from Col du Géant, a late normal quartz-filled fault can be seen crosscutting the South Canigou Shear Zone.

Figure 13. Simplified 2D-model summarizing three stages of the late-Variscan tectonic evolution of the southern Canigou gneiss dome. 


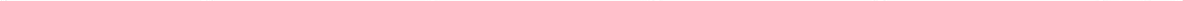



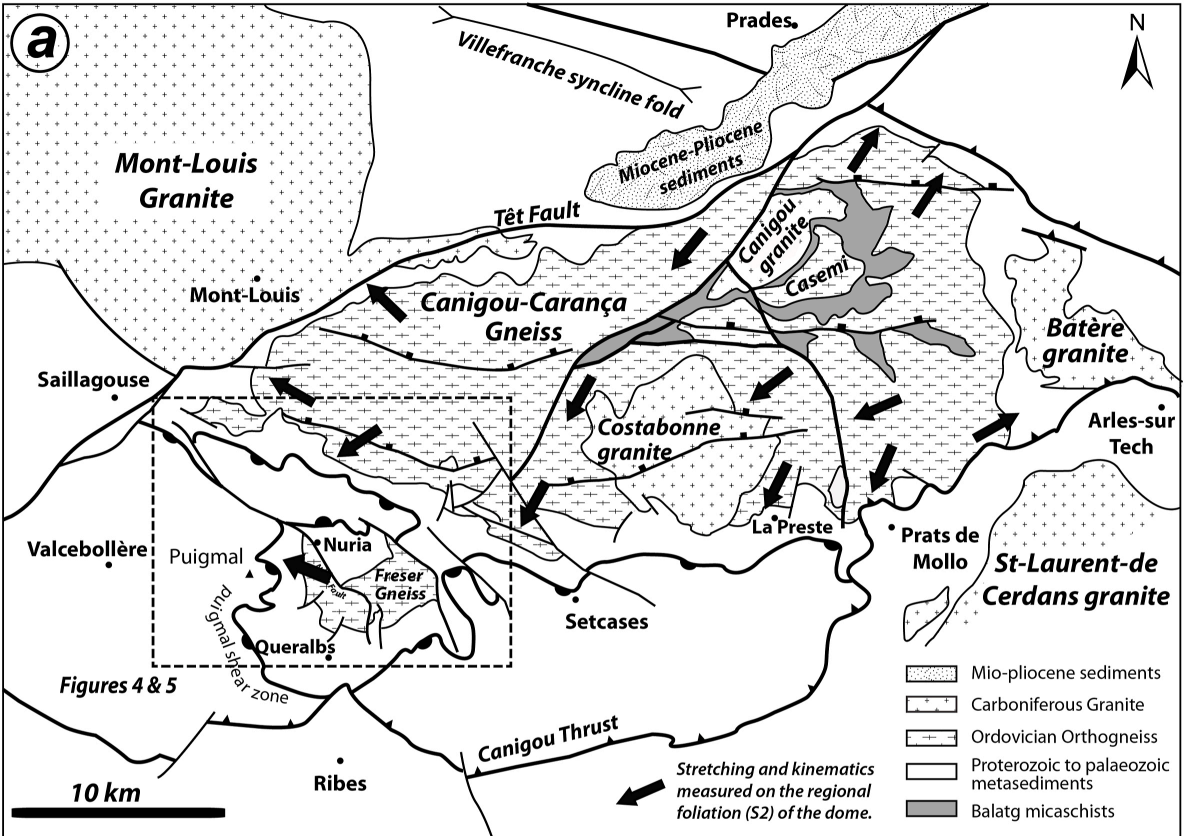

\section{Ordovician orthogneisses:}

Carboniferous granites:

Canigou gneiss (G2) : ca. 471 Ma (Cocherie et al, 2005) Carança : 304.7+/-1.1 (U/Pb Zr) (Denèle et al., 2014) Canigou (G1): ca. $477 \mathrm{Ma}$ (Cocherie et al, 2005) Casemi : ca. 445-451Ma (Casas et al, 2010) Freser: ca. $457 \mathrm{Ma}$ (Martinez et al, 2008)

\section{(b)} N173 ${ }^{\circ} \mathrm{E}, 8^{\circ} \mathrm{E}$

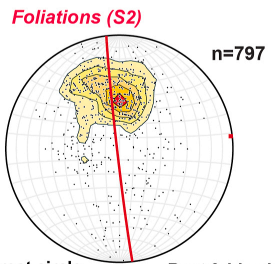

Best fold axis $83^{\circ} / 02^{\circ}$
Stretching Lineations (L2)

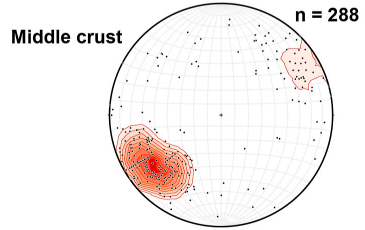

Mean lineation $225^{\circ} 17^{\circ}$
Stretching Lineations + shear senses

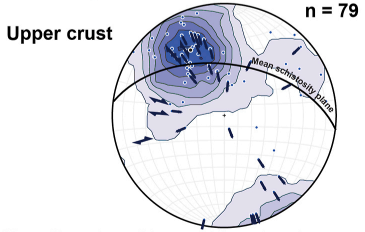

Mean lineation Mean schistosity plane $333^{\circ} / 34^{\circ}$ $98^{\circ} \mathrm{E}, 52^{\circ} \mathrm{N}$ 
A) Recumbent fold ( «Alpine» Nappe) (Guitard, 1970)

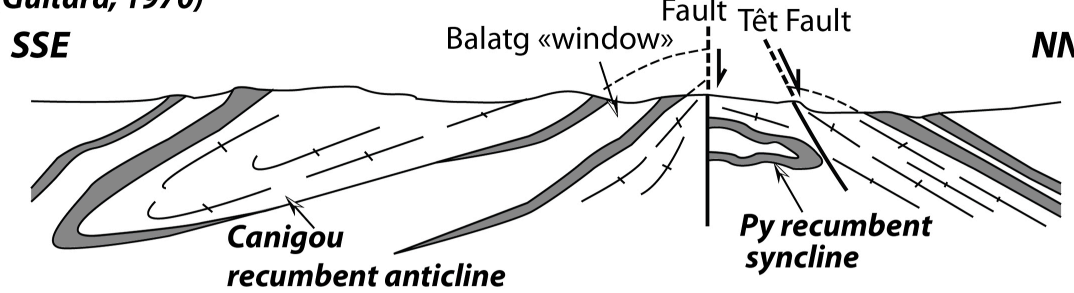

B) Thrusts ( «Alpine» Nappe)

(Lagarde, 1978; Soliva, 1989)

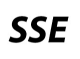

C) Laccolith intrusion

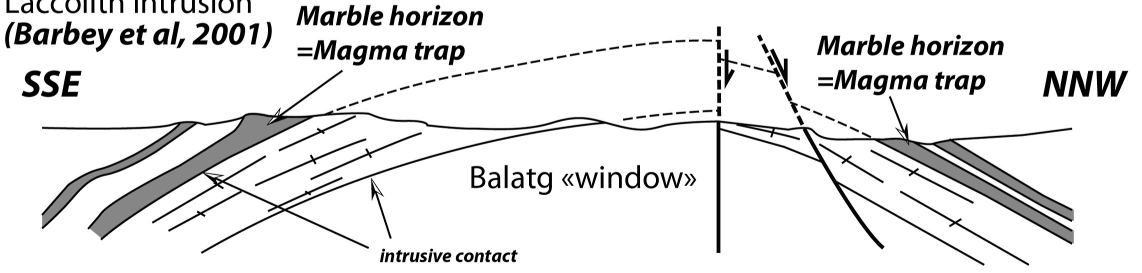

\section{syncline}
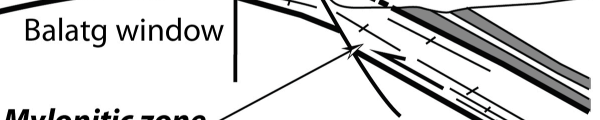

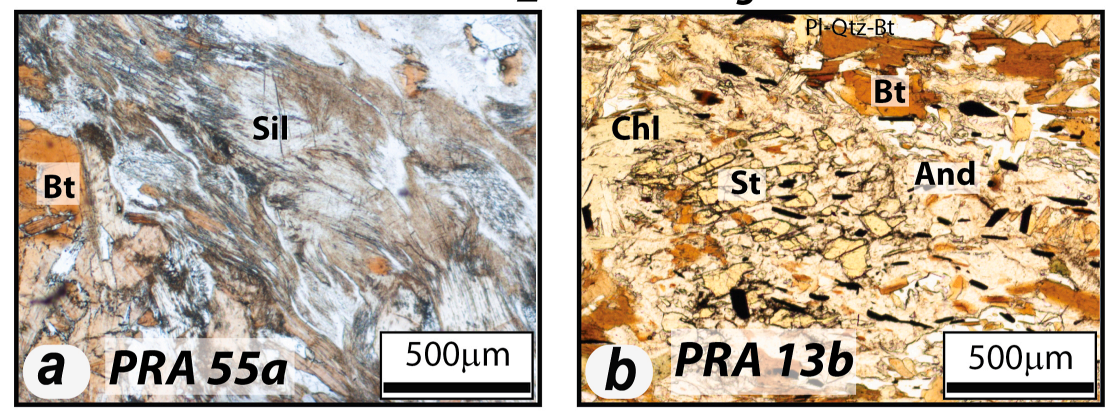

S2

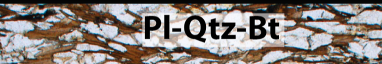
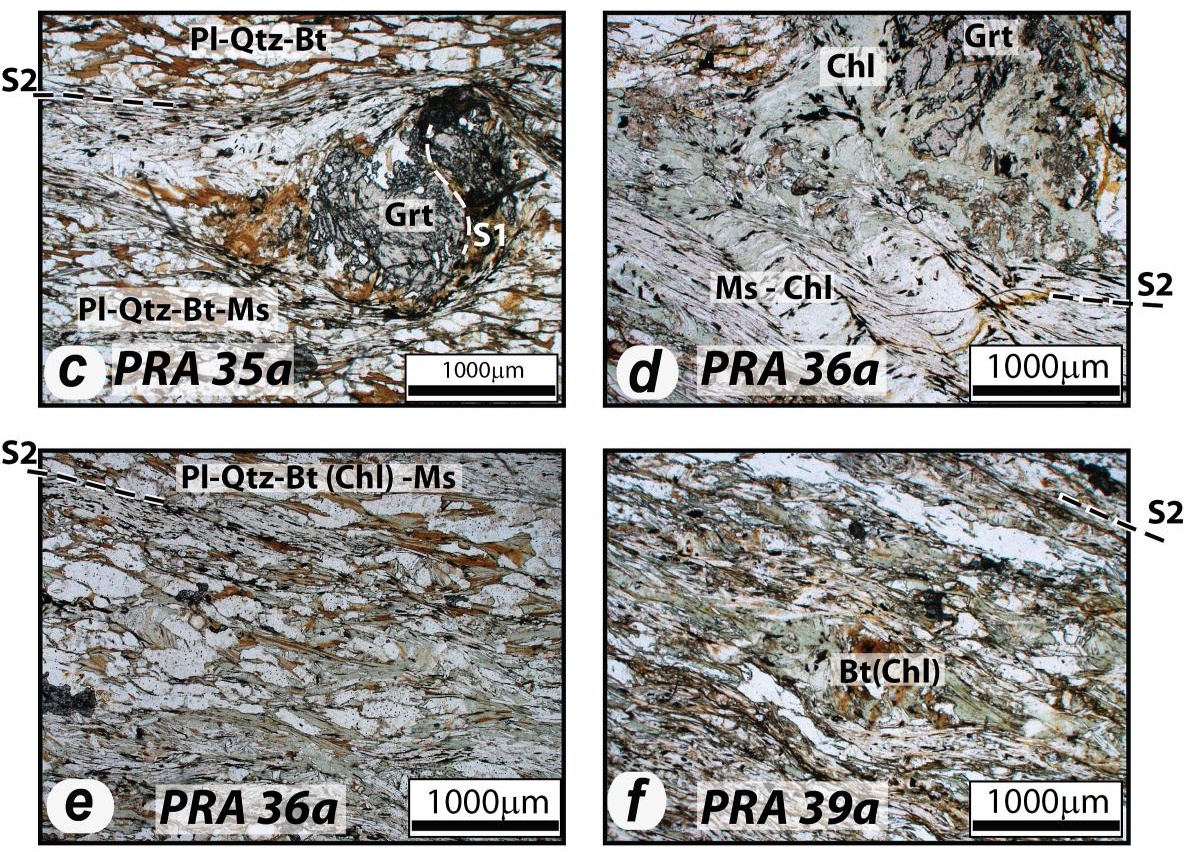

\section{Upper unit_Puigmal unit}

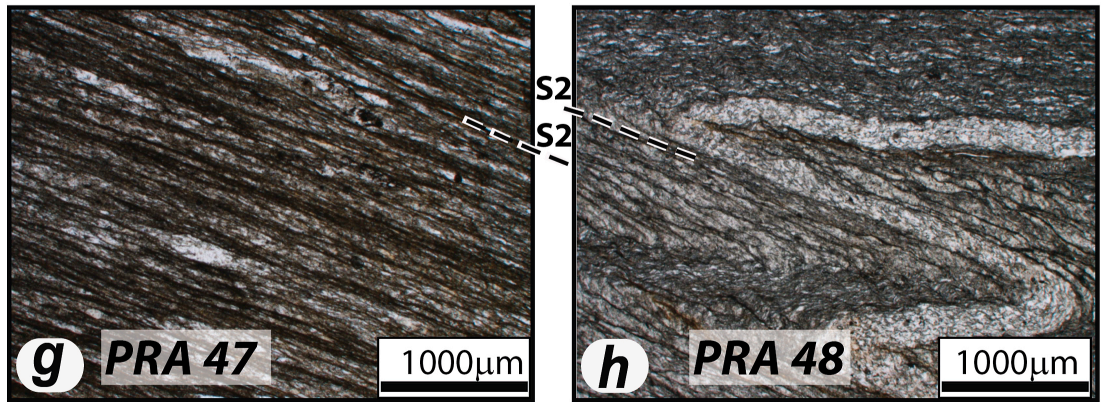





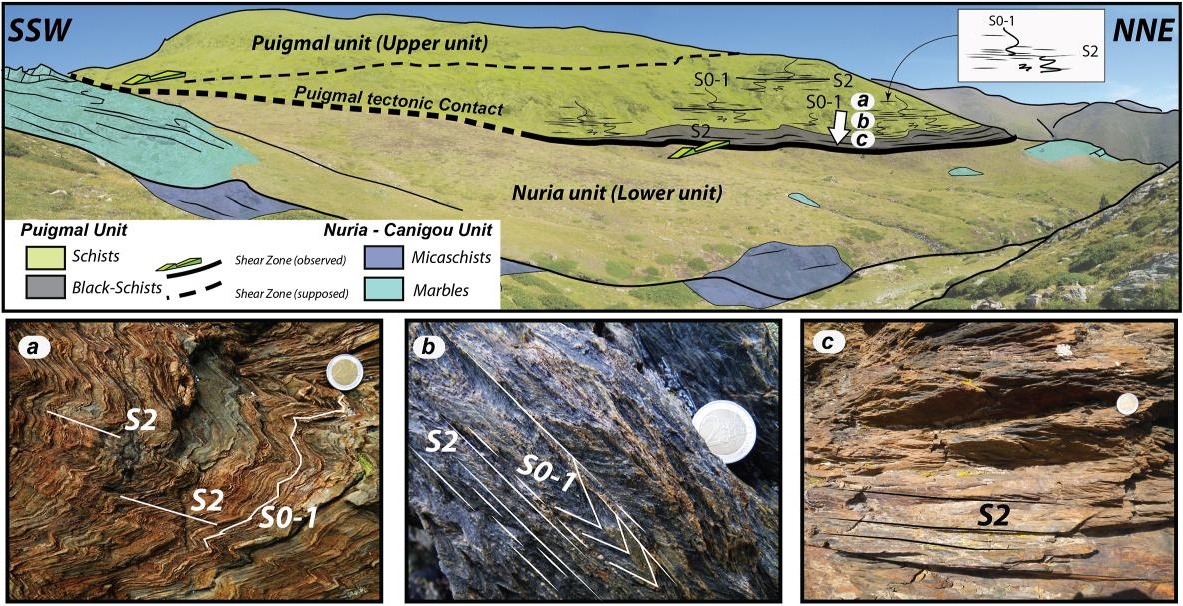




\title{
Puigmal
}

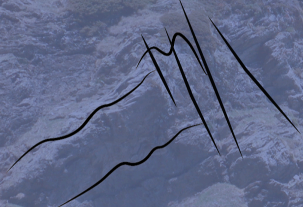

\section{Puigmal Unit}

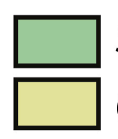

\author{
Schists \\ Shear Zone
}

Nuria - Canigou Unit

Carbonates
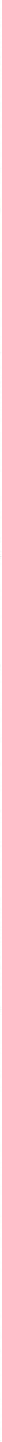


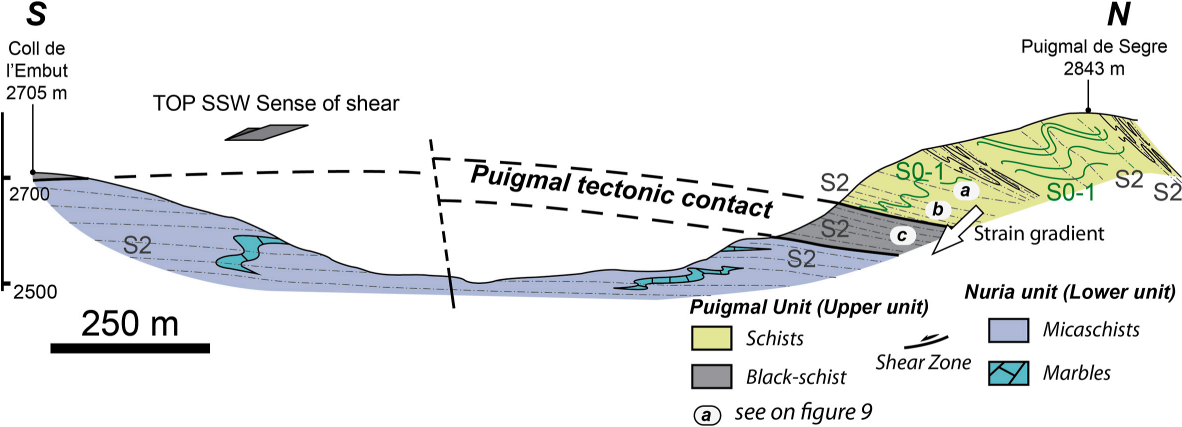




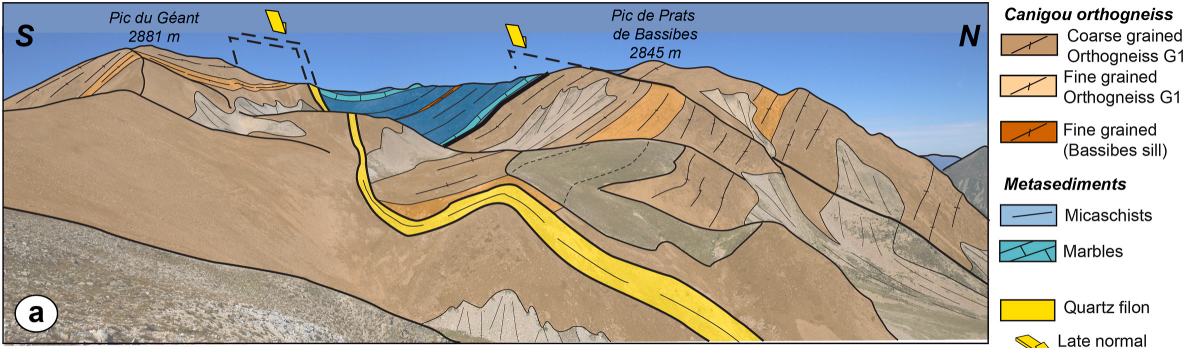

Canigou orthogneiss

7 Coarse grained

Orthogneiss G1

Fine grained

Orthogneiss G1

$\triangle$ Fine grained

(Bassibes sill)

\section{Metasediments}

$\square$ Micaschists

$\exists$ Marbles

$\square$ Quartz filon

Late normal

faults

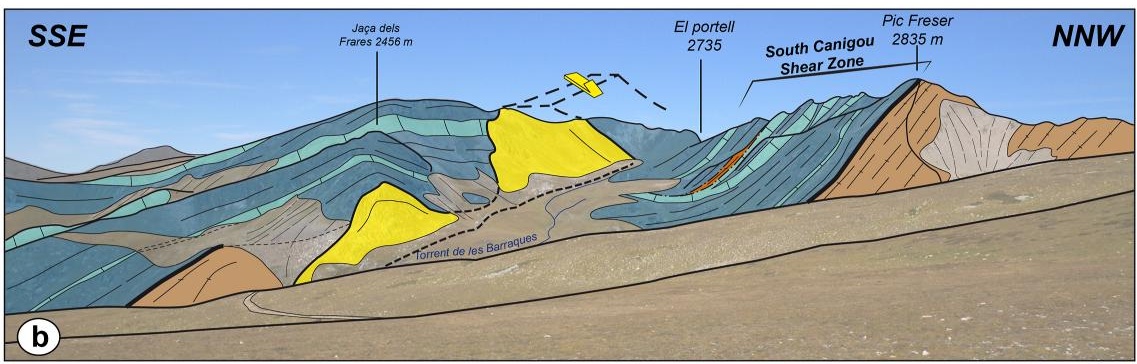


a

before $\sim 310$ ma Moderate crustal thickening

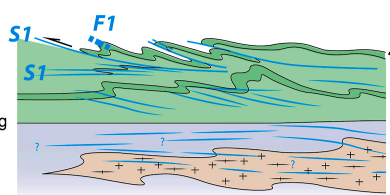

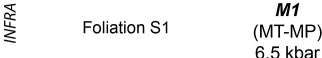
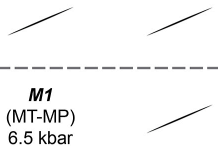

NE
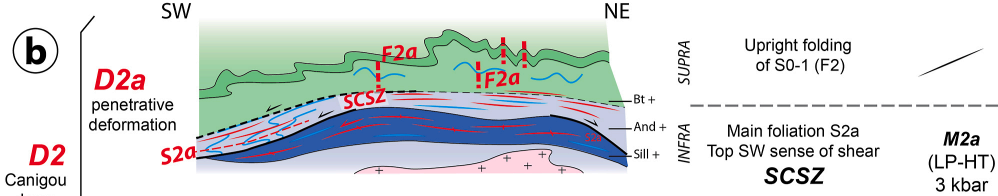

NE

dome 310-305Ma

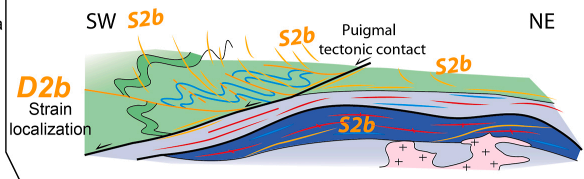

\section{Foliation S2b Puigmal tectonic}

NE LP-HT) 3 kbar
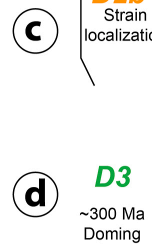

SW

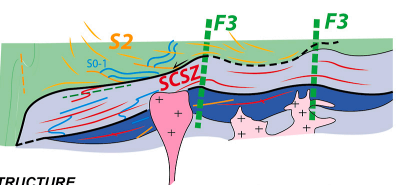

\section{SUPRASTRUCTURE}

Leucogranite

Puigmal unit - Upper unit

+ ("Granite Profond du Canigou»)

\section{INFRASTRUCTURE}

Nuria-Canigou unit - Lower unit

$+\quad$ Calc-Alcaline Granite

(«Costabone Granite») $\$$ shear zones (Greenschists)
$\vdots$ Top SW sense of shear

\section{Folding of S2 (F3)}

$\lesssim$ Folding of Puigmal contact

$\begin{array}{ccc}\text { Crenulation folding of the S2 } & \text { Contact } \\ & \text { Upright folds (F3) } & \text { metamorphism } \\ \text { (Skarns) }\end{array}$

M2b

(LP-LT)

Greenschist facies

Leucogranites

(Granite profond Canigou)
Calc-Alcaline granites (Costabone) 


\begin{tabular}{|c|c|c|c|c|c|c|c|c|c|c|}
\hline \multicolumn{4}{|c|}{ DEFORMATION STAGES } & \multirow[b]{2}{*}{ Ages } & \multicolumn{3}{|c|}{ Nuria-Canigou unit - Lower Unit } & \multicolumn{2}{|c|}{ Puigmal unit - Upper Unit } & \multirow[b]{2}{*}{ Interpretation } \\
\hline $\begin{array}{c}\text { Guitard et } \\
\text { al., 1992 }\end{array}$ & $\begin{array}{l}\text { Laumonier } \\
\text { et al., } 2010\end{array}$ & $\begin{array}{c}\text { Denèle et } \\
\text { al., 2014 }\end{array}$ & This study & & Structure & Metamorphism & Magmatism & Structure & Metamorphism & \\
\hline D5 & $\mathrm{D} 2 \mathrm{~b}$ & $\mathrm{D} 2 \mathrm{~b}$ & D3 & $\begin{array}{c}305-290 \\
\mathrm{Ma}\end{array}$ & \begin{tabular}{|c|} 
Crenulation folding of the \\
regional foliation, with \\
upright folds. E-W \\
crenulation lineation \\
\end{tabular} & $\begin{array}{l}\text { Maximum greenschist facies + Skarn } \\
\text { development around the calc-alkaline } \\
\text { granite }\end{array}$ & $\begin{array}{l}\text { Calc-alkaline granite emplacement } \\
\text { (Costabone granite); 302 Ma (Laumonier } \\
\text { et al., 2015) }\end{array}$ & $\begin{array}{c}\text { (Dextral reverse) } \\
\text { Mylonites and } \\
\text { Kilometer-scale upright } \\
\text { and slightly inclined } \\
\text { open folds } \\
\end{array}$ & & $\begin{array}{l}\text { E-W fold axes (doming and shortening) during } \\
\text { Transpression, reverse dextral shear zone }\end{array}$ \\
\hline & & & $D 2 b$ & \multirow[b]{2}{*}{$\begin{array}{c}\text { 310-305 } \\
\mathrm{Ma}\end{array}$} & \begin{tabular}{|c|} 
Extensional shear zone with \\
top the South-West \\
kinematics. Mylonites \\
parralel to Saz. (localised \\
deformation).
\end{tabular} & \multirow{2}{*}{$\begin{array}{c}\text { Greenschist facies (Chlorite bearing); } \\
\text { M2b } \\
\text { HT-LP Metamorphism (Amphibolite } \\
\text { facies); M2a: BP-HT }\end{array}$} & \multirow{2}{*}{$\begin{array}{c}\text { Emplacement of peraluminous granites } \\
\text { (304-306 Ma (Granite peralumineux } \\
\text { Carança; Ax les Thermes), Denèle, et al., } \\
\text { 2014) }\end{array}$} & $\begin{array}{l}\text { Extensional shear zone } \\
\text { at the top of the } \\
\text { Puigmal unit (ex: } \\
\text { Puigmal) }\end{array}$ & \multirow[b]{2}{*}{ Epimetamorphic conditions } & \multirow{2}{*}{\begin{tabular}{|} 
Main phase of deformation, associated to South- \\
Westward shearing during Exhumation of the \\
Canigou orthogneisses. Exhumation during a \\
dextral transpressional regime (Cochelin et al., \\
2017)
\end{tabular}} \\
\hline D4 & D2a & D2a & $D 2 a$ & & \begin{tabular}{|c|} 
Subhorizontal regional \\
pervasive foliation \\
associated to a NW-SE \\
trending strtething ineation \\
with top-to-the-South West \\
shear sense (South Canigou).
\end{tabular} & & & $\begin{array}{l}\text { Extensional shear zone } \\
\text { (ex: Têt SZ) Folding, } \\
\text { with steep axial plane } \\
\text { schistosity }\end{array}$ & & \\
\hline \multirow[t]{2}{*}{ D3 } & D1a-b-c & D1 & D1 & $\begin{array}{c}350-320 \\
\mathrm{Ma}(?)\end{array}$ & $\begin{array}{c}\text { D1 foliation (well preserved } \\
\text { in Balatg micaschists) }\end{array}$ & $\begin{array}{l}\text { Kyanite relic (Guitard, 1970), MT-MP } \\
\text { Metamorphism (De Hoÿm de Marien et } \\
\text { al., 2019) }\end{array}$ & & ? & Unmetamorphic conditions & $\begin{array}{l}\text { N-S Convergence stage. Fold and thrust belt } \\
\text { (suprastructure) Foreland deformation }\end{array}$ \\
\hline & & & $\begin{array}{l}\text { Pre- } \\
\text { Variscan } \\
\text { Stage }\end{array}$ & $\begin{array}{c}475- \\
450 \mathrm{Ma}\end{array}$ & ? & $\begin{array}{l}\text { Contact metamorphism (laccolith } \\
\text { intrusions) }\end{array}$ & Emplacement of granitic laccoliths & & Contact metamorphism? & \\
\hline
\end{tabular}




\section{Highlights}

- Strain localization within extensional shear zones confined to the roof the dome

- Local NE-SW extension induce exhumation of metamorphic rocks during regional cooling

- The dome shape was acquired during the main tectonic phase (D2), under transpression 


\section{Declaration of interests}

$\bigotimes$ The authors declare that they have no known competing financial interests or personal relationships that could have appeared to influence the work reported in this paper.

$\square$ The authors declare the following financial interests/personal relationships which may be considered as potential competing interests: 